University of Chicago Law School

Chicago Unbound

Journal Articles

Faculty Scholarship

1988

\title{
Bargaining after the Fall and the Contours of the Absolute Priority Rule
}

Douglas G. Baird

Thomas H. Jackson

Follow this and additional works at: https://chicagounbound.uchicago.edu/journal_articles

Part of the Law Commons

\section{Recommended Citation}

Douglas G. Baird \& Thomas H. Jackson, "Bargaining after the Fall and the Contours of the Absolute Priority Rule," 55 University of Chicago Law Review 738 (1988).

This Article is brought to you for free and open access by the Faculty Scholarship at Chicago Unbound. It has been accepted for inclusion in Journal Articles by an authorized administrator of Chicago Unbound. For more information, please contact unbound@law.uchicago.edu. 


\title{
Bargaining After the Fall and the Contours of the Absolute Priority Rule
}

\author{
Douglas G. Baird $\dagger$ \\ Thomas H. Jackson $\dagger \dagger$
}

The absolute priority rule provides that in a reorganization senior owners are paid in full before junior owners are paid anything. ${ }^{1}$ When a firm owes more than its assets are worth, the shareholders receive nothing unless the creditors consent. Under the 1978 Bankruptcy Code, consent can be given through a classwide vote of creditors. A single uncompromising creditor's objection is not sufficient to prevent the participation of shareholders. Nevertheless, the absolute priority rule and its rhetoric stand in distinct contrast to the distrust of market mechanisms and ex ante bargains that pervades both the practice of bankruptcy and discussions of bankruptcy policy. Walter Blum's classic essay, The Law and Language of Corporate Reorganizations, ${ }^{2}$ takes as its theme this tension between the need for respecting the pre-bankruptcy bargain and the harshness of vindicating that bargain after the fact. Recognition of that tension permeates much of what he has written since. ${ }^{3}$ The insights contained in his work establish the common ground upon which all modern bankruptcy scholars stand.

$\dagger$ Professor of Law, The University of Chicago.

t† Arnold Leon Professor of Law and Dean, University of Virginia School of Law. We owe much to the advice and sage counsel of Walter Blum. We also thank William Baxter, Lucian Bebchuk, Victor Brudney, Robert Clark, Frank Easterbrook, Russell Eisenberg, Richard Epstein, Stephen Harris, Reinier Kraakman, Mitchell Polinsky, Richard Posner, Robert Rasmussen, Myron Scholes, and George Triantis for their help. Research support was provided by the John M. Olin Program in Law and Economics at the Harvard Law School.

' The absolute priority rule was first named in James C. Bonbright and Milton M. Bergerman, Two Rival Theories of Priority Rights of Security Holders in a Corporate Reorganization, 28 Colum.L.Rev. 127 (1928).

${ }^{2}$ Walter J. Blum, The Law and Language of Corporate Reorganizations, 17 U.Chi.L.Rev. 565 (1950).

${ }^{3}$ See, e.g., Walter J. Blum, The "New Directions" for Priority Rights in Bankruptcy Reorganizations, 67 Harv.L.Rev. 1367 (1954); Walter J. Blum, Full Priority and Full Compensation in Corporate Reorganization-A Reappraisal, 25 U.Chi.L.Rev. 417 (1958); Walter J. Blum, Corporate Reorganization Doctrine as Recently Applied by the Securities and Exchange Commission, 40 U.Chi.L.Rev. 96 (1972); Walter J. Blum and Stanley A. Kaplan, The Absolute Priority Doctrine in Corporate Reorganizations, 41 U.Chi.L.Rev. 651 (1974). 
The dispute in Case v. Los Angeles Lumber Products ${ }^{4}$ and the other opinions that gave rise to much of Walter Blum's work, however, developed only after the absolute priority rule was well into middle age. These cases all involved battles between a creditor or group of creditors on the one hand and shareholders on the other. In its infancy, the absolute priority rule involved not two parties but three. In this paper, we make an effort to extend Walter Blum's work. We do so both by looking at the most recent disputes involving the absolute priority rule and by going back in time to when the absolute priority rule first appeared as a rule governing bargaining among multiple parties inside of bankruptcy.

We are honored that our effort appears in an issue of the University of Chicago Law Review dedicated to Walter Blum. His work on the absolute priority rule inspired the first effort one of us made as a legal scholar. The other has enjoyed the privilege of having Walter Blum as a colleague at the Law School for the last eight years and owes much of his understanding of bankruptcy law to him. This paper itself draws much inspiration from Walter Blum's insistence that the absolute priority rule is central to an understanding of corporate reorganizations and that to understand the rule one must begin with its history.

At the end of the last century, many of this country's railroads had their capital structures reorganized under the aegis of a federal court. At the behest of a creditor who was friendly to management, the court would appoint a receiver. The law of equity receiverships was largely judge-made, or, more accurately, lawyer-made. The elite law firms of the era were intimately involved with the development of this doctrine. ${ }^{6}$ It was a time when giants walked the earth. Robert Swaine was only an associate at the Cravath firm when he made his contribution to the absolute priority rule while working on the restructuring of the Frisco line out of a Pullman car in a railroad yard in Jefferson City. ${ }^{7}$

During the course of the typical equity receivership, the old managers would continue to run the railroad and would conduct elaborate negotiations with representatives of the senior creditors. At the end of the day, the senior creditors would find their inter-

308 U.S. 106 (1939).

- Note, Giving Substance to the Bonus Rule in Corporate Reorganizations: The Investment Value Doctrine Analogy, 84 Yale L.J. 932 (1975).

- For a discussion of the role the legal profession played in equity receiverships, see Robert W. Gordon, Legal Thought and Legal Practice in the Age of American Enterprise, 1870-1920, in Gerald L. Geison, Professions and Professional Ideologies in America (1983).

7 Robert Taylor Swaine, 2 The Cravath Firm and its Predecessors 169-75 (1948). 
ests substantially trimmed. The old shareholders (who often included the old managers) would still retain a small interest (provided, in many cases, that they contributed additional capital to the firm). General creditors were often frozen out or given only a small amount for their interests. The dynamics that brought about this result are not easy to understand, but the doctrines developed during this period are with us still. The most significant of these is the absolute priority rule. In this paper, we want to focus, not on the historical question of how the absolute priority rule came into being, but rather on the continuing importance of the freeze out problem that gave rise to the absolute priority rule and the role the absolute priority rule does and should play given our existing Bankruptcy Code. To do this, we begin with some basic observations about corporate finance.

Part of the initial bargain among those who contribute capital to a firm is an agreement about how assets of the firm will be divided if there is a day of reckoning on which everyone's ownership interest is valued. In most firms, one set of owners will take before others. ${ }^{8}$ Debt will be paid before equity. In many firms, there are multiple layers of ownership. There are, commonly, secured creditors, general creditors, subordinated debenture holders, preferred stockholders, and common stockholders, among others. Why those who contribute capital to a firm choose to structure ownership interests in this fashion is one of the central questions of corporate finance. ${ }^{8}$

Quite apart from the question of why there are multiple layers of ownership, however, are the problems associated with recognizing this hierarchical structure at the time of the reckoning. Sorting out the different ownership layers often is not an easy affair when the firm is to stay intact as a going concern. When some of the old owners are to remain involved with the firm after the accounting, they may be in a position to renegotiate their original bargain. The supplier who is owed money may condition delivery of further supplies on its past debts being paid in full. The manager who agreed to work for the old firm in return for equity may insist on equity in the new firm as well. The shareholder who offers new capital may insist that it have an equity interest in the new firm even though

B By "owners," we mean those who have some claim to the income stream or assets of the enterprise. As such, it includes creditors and holders of equity interests alike, instead of the conventional equation of ownership with common stock.

8 The seminal article is Franco Modigliani and Merton H. Miller, The Cost of Capital, Corporation Finance and the Theory of Investment, 48 Am.Econ.Rev. 261 (1958). 
there is not enough cash to pay those senior to it.

To the extent that the junior owners can offer new supplies, expertise, or capital on terms more favorable than anyone else, it is in everyone's interest that they do so. In negotiations involving prior owners who are also future suppliers, striking a deal requires distinguishing between their rights as existing owners of the firm and their ability to provide a new input to the firm on favorable terms. It also requires some mechanism for determining who may bargain on behalf of the firm. Someone must not only set the terms of the bargain, but also guard against the possibility that the old owners are offering something that they are already legally obliged to supply the firm.

Although these negotiations are the lifeblood of nonbankruptcy workouts and bankruptcy practice, the rules that should govern these negotiations are largely unexplored in the academic literature. The rules must tell us how these negotiations are to be conducted and whose consent is needed to renegotiate the original ordering of ownership interests. In this paper, through our examination of the absolute priority rule, we look at the principal substantive provision governing the renegotiations among owners of a firm when there is a day of reckoning. ${ }^{10}$

We focus on a narrow category of firms in economic trouble. Many cases do not present difficult bargaining problems. Some firms that cannot meet their obligations are not worth keeping intact as going concerns. These are the manufacturers that sell computers no one will buy and the restaurants that serve food no one will eat. The firm's assets are worth more sold piece by piece than as a unit. In those cases, if the most senior creditor is owed more than what the assets can be sold for, the appropriate course is to allow the senior creditor to sell the assets and keep the proceeds. ${ }^{11}$ There is no bargaining problem because there is nothing to bargain

${ }^{10}$ In earlier studies of the principles of corporate reorganization, we argued that the existing rules governing corporate reorganizations under the Bankruptcy Code were hard to defend under any conditions and could be justified, if at all, only in the case of closely held firms. See Douglas G. Baird, The Uneasy Case for Corporate Reorganizations, 15 J.Legal Stud. 127 (1986) and Thomas H. Jackson, The Logic and Limits of Bankruptcy Law ch. 9 (1986). In that work we questioned whether the procedures of Chapter 11 are superior to those of Chapter 7 for maximizing returns to the owners as a group. See also, Mark J. Roe, Bankruptcy and Debt: A New Model for Corporate Reorganization, 83 Colum.L.Rev. 527 (1983).

"The existing Bankruptcy Code provides for this result. A secured creditor is entitled to have the automatic stay lifted and to resort to its state law foreclosure remedies when the debtor has no equity in the property and the property is not needed for a reorganization. 11 U.S.C. $\$ 362$ (d) (1982). 
over: no other group of owners holds anything that is of value to the senior creditor. ${ }^{12}$

In other cases, the firm, although insolvent, is worth preserving, but the existing owner-managers need to be replaced. In these cases the appropriate course also is to allow the most senior creditor (assuming again it is owed more than the firm is worth) to sell the assets of the firm either to a third party or to itself. ${ }^{13}$ The only difference is that the senior creditor should now sell the assets as a unit rather than piece by piece. The junior creditors and the shareholders cannot complain because they have bargained for a position inferior to that of the senior creditor with respect to all the assets being sold. The senior creditor is entitled to be paid in full before anyone junior to it receives anything. ${ }^{14}$ Again, there is nothing to bargain over vis-a-vis the existing owners, as none of them have anything to offer the most senior creditor. Indeed, the firm is more valuable without them than with them.

As applied to these cases, the absolute priority rule simply restates the idea of a layered ownership structure in which one owner has bargained for the right to be paid before others. One can look exclusively to the extant agreements among the participants as owners, because none of them bring any special advantages (and hence bargaining strength) relevant to the firm's future. Harder cases, however, arise when the firm, although insolvent, is worth keeping intact as a going concern and an existing owner is a peculiarly well-positioned source of capital, supplies, or expertise to the firm or otherwise has the ability to strike a deal that gives it a better position than its preexisting position in the ownership hierarchy entitles it to. ${ }^{15}$ The problem is most stark when the firm is

${ }^{12}$ We discuss in detail in Part I of this paper a two-party case where Manager may contribute something of value and hence where there may be something to bargain over. But these are cases where there is something valuable to be contributed in the future; cases of firms that will continue.

${ }^{13}$ There may be assets that a secured creditor cannot effectively sell. For example, a supplier of a unique and valuable input may refuse to deal with new owners. These cases, however, seem appropriately lumped together with cases where the current owner-managers bring special value, for it is their presence that determines whether the supplier will continue to supply. Similarly, nonassignable contracts and the like generally fit into the same category, to the extent they determine whether an assignment has occurred by looking to the firm's ownership structure. Contracts that look solely to corporate form-is it A Corp. or is it B Corp.-are perhaps distinct, but for analytical purposes, we will put such formal contracts aside.

14 Whether this result is in fact reached under existing law is not at all clear, however. See Baird, 15 J.Legal Stud. 127 (cited in note 10).

15 Note that the old owner will have bargaining leverage only if it is otherwise in a position to provide capital, supplies or expertise on terms more favorable than others. The 
worth less than what the most senior creditor is owed and the senior creditor has reason to recombine with the old shareholder. ${ }^{16}$ The effect of the recombination would be to freeze out an intermediate creditor.

It might seem that the intermediate creditor has little to complain about. The senior creditor is entitled to exercise its default rights. The procedures that the senior creditor must use to foreclose upon the property are designed, at least in principle, to prevent the senior creditor from acquiring the entire firm when that firm is worth more than what the senior creditor is owed. If, upon compliance with those procedures, the remaining assets of the firm prove to be worth less than what is owed the senior creditor, the effect of the original deal the firm struck with its creditors is that the senior creditor gets those assets, and the intermediate creditor gets nothing. One can argue that intermediate creditors have lost nothing when the senior creditor exercises those rights and then decides to share the assets it thereby acquires with the old shareholder.

Under this view, the senior creditor, having the exclusive right to the firm's assets following foreclosure, should be able to convey an interest in them to anyone it pleases. ${ }^{17}$ That it is willing to share those assets with the old shareholder suggests that it sees advantage in doing so. Perhaps the shareholder will bring new capital when no one else will. Perhaps the shareholder has firm-specific skills that the senior creditor wants to preserve. The old shareholder is acquiring an interest because the senior creditor has concluded doing so is in its interest, not because of the old shareholder's preexisting status. The senior creditor would be as willing to deal with the intermediate creditor, indeed, anyone at all, if the party were willing to contribute capital or provide the needed ex-

firm does not have to bargain with the old owners if it can get the same deal from others without having to take a prior ownership interest into account.

${ }^{16}$ Other creditors might, as noted earlier, be valuable suppliers of future goods or services and be entitled to something in that capacity. For purposes of this paper, however, we focus on the cases where the equity owners-managers are the group bringing something of value to the firm's future.

17 The valuation may not be believable. To demonstrate valuations, default rules typically give a debtor the right to force liquidation of the collateral by a secured party. See, e.g., U.C.C. \$ 9-505 (1978). A similar rule may be desirable to protect general creditors from valuation worries. These worries, however, would provoke a response, forced sale procedures, distinct from the one under discussion, simply banning the transaction. The doctrine we reexamine here derived from Northern Pacific Ry. v. Boyd, 228 U.S. 482 (1913). Boyd involved a judicial foreclosure sale, and so was not responding to a worry over the liquidation value of the collateral. Boyd, however, may have been responding to another type of valuation worry caused by a foreclosure sale which we discuss in Part II. 
pertise. The senior creditor, in other words, presumably combines its assets with something new being contributed by the old shareholders, and this transaction thereby violates no rights of the intermediate class.

In Northern Pacific Railway v. Boyd, ${ }^{18}$ however, a sharply divided Supreme Court struck down a transaction that froze out an intermediate class of owners while granting some ownership rights to former shareholders. The Court held that any restructuring of the firm must take note of the intermediate creditors. Exactly how the intermediate creditor was to be treated and what kinds of exceptions needed to be made to the general rule were left to future cases. The Court, for example, later excepted contributions of new capital by a junior owner. ${ }^{19}$ The basic lesson of Boyd, however, is that leaping over an intermediate class triggers special scrutiny. This is the crucial feature of the absolute priority rule that we want to focus on because it is central to the problem of renegotiations in bankruptcy. ${ }^{20}$

Given our characterization of this problem, it is not at all clear why passing over an intermediate class is objectionable. We have described any recombination of a senior creditor with the old shareholder as consisting of two separate steps: a foreclosure on the assets by the senior party that is followed by a recombination of those assets with the old shareholder for a reason of the senior creditor's choosing. Boyd, however, rests on a different description

18228 U.S. 482 (1913).

19 Kansas City Ry. Co. v. Cent. Union Tr. Co., 271 U.S. 445, 455-56 (1926).

${ }^{20}$ See generally, Harry G. Guthmann, Absolute Priority in Reorganization: Some Defects in a Supreme Court Doctrine, 45 Colum.L.Rev. 739 (1945). In Case v. Los Angeles Lumber Products Co., 308 U.S. 106, 115 (1939), the Supreme Court held that the language "fair and equitable" in $\$ 77 \mathrm{~B}$ of the Bankruptcy Act of 1898 "are words of art [that] had acquired a fixed meaning" through equity receivership cases such as Boyd, 228 U.S. 482 (although that precise phrase, ironically, has not been used in any of the cases cited by the Case court). 11 U.S.C. $₹ 1129(\mathrm{~b})(1)$ continues the requirement that a plan be "fair and equitable," while 11 U.S.C. $\$ 1129(b)(2)$ has codified on a class-wide basis some of the most prominent features of the "absolute priority rule" by specifically including them in the requirement that a plan "be fair and equitable with respect to a class." The rule of Boyd is referred to in the floor statements concerning 11 U.S.C. $\$ 1129(b)(2)$, where it is noted that "a senior class will not be able to give up value to a junior class over the dissent of an intervening class unless the intervening class receives the full amount, as opposed to value, of its claims or interests." 124 Cong.Rec. 32408 (Sept. 28, 1978).

The rule announced by the Boyd court was not limited to bankruptcy; indeed, as Boyd involved an equity receivership, its rule did not even arise out of bankruptcy. Because the Boyd decision was decided before Erie R. Co. v. Tompkins, 304 U.S. 64 (1938), however, one can question whether it exists in state law outside of bankruptcy. We assume here that it, like most Supreme Court commercial law doctrines from that period, is accepted as a general feature of state law. 
of the transaction: The old shareholder starts with an ownership interest in the firm that is subject to the claims of its general creditors. She then strikes a deal with the senior creditor, and immediately finds herself with an ownership interest in the same firm that is free of those claims.

Sharply different initial conclusions follow from this vision of the transaction. The general creditors may not have been entitled to anything if all the firm's assets were converted to cash today, but a recapitalization is occurring, not a dismemberment of the firm. Where the firm continues, the general creditors, but for the restructuring, might have something of value that the restructuring takes away and gives to the shareholder. Even though the firm will likely not be able to pay off the secured creditor, the possibility that the firm will do much better than expected makes the general creditors' right to reach the assets of the firm before the shareholders worth something. ${ }^{21}$

The general creditors' objection is not to the senior creditor's right to foreclose and sell the firm as a going concern. By the nature of the position each took in the firm, the general creditors cannot complain when the senior creditor uses its default right to get paid ahead of them out of the firm's assets. Their objection instead goes to the shareholder's recapture of an interest in the firm. Under this argument, the general creditors should be able to object if the old shareholder recovers something over which the general creditors have a prior claim and does so by means of a transaction in which the general creditors have no voice.

Viewed this way, the general creditors should be able to prevent the old shareholder from engaging in a transaction that freezes out the interests of the general creditors while leaving something for the old shareholder. It is not enough for the shareholder to strike a deal with the senior creditor in order to keep an interest in the firm. The shareholder must also strike a deal with the general creditors, as they have the right to enjoy the firm's potential revenues before the shareholder. Because this transaction has the effect of allowing the old shareholder to claim an interest in the firm free of the claims of the general creditors, it can be seen as a fraudulent conveyance. ${ }^{22}$

21 The probability distribution has a "tail" at the upper end under which the firm would generate enough to pay off the secured creditor in full and still leave something for the general creditors. In theory, the same kind of tail, albeit necessarily smaller still, leaves something of value for the holder of the equity residual.

${ }^{22}$ See Statute of 13 Elizabeth (1571); Uniform Fraudulent Transfer Act (1985); Uni- 
An understanding of the absolute priority rule, then, must turn on choosing between two radically different ways of viewing the same transaction. From one perspective, the transaction is viewed as a proper foreclosure, followed by a recombination between the senior creditor (or other buyer of assets) and the old shareholder (who is making some contribution to the firm that entices the senior creditor, or other buyer, to share its assets with the old shareholders). From the other perspective, the transaction is viewed as a conveyance that, by preferring holders of equity interests over creditors, violates the payout norms implicit in the debtor-creditor relation.

The absolute priority rule, in short, was originally about a three-party transaction where the issue was whether a senior claimant with the right to the entire firm in a liquidation could ignore an intermediate party if it chose to include old equity holders in the reorganized firm. This aspect of the rule, the heart of the holding in Boyd, has been transported uncritically into the Bankruptcy Code even though its superiority over the competing rule-treating the shareholders as contributing something of value to the reorganized firm and hence permitting the freeze-out-is far from obvious.

In this paper we reexamine the premises of the absolute priority rule from the general perspective of the renegotiation problem. We first revisit the dynamics of default and liquidation in the twoparty case, the case currently generating the most controversy, as embodied in the Supreme Court's recent opinion in the Ahlers case. ${ }^{23}$ The two-party case focuses directly on the contractual rene-

form Fraudulent Conveyance Act (1918). A variant on this transaction would involve not the skipping over of an intervening class, but a restructuring where a class of creditors recombines with a subset of the old shareholders, giving some of the old shareholders new equity and freezing out the others. The transaction, which arguably violates the norm that the members of the same class receive the same package of rights, is analytically no different than the transaction we examine in text. Courts, however, have been more tolerant of such transactions. See, e.g., In re Toy \& Sports Warehouse, Inc., 37 Bankr. 141 (Bankr.S.D.N.Y. 1984) (common stockholders excluded from reorganized company; equity went to new investor who was cousin of president; jobs went to old president and his son).

${ }^{23}$ Norwest Bank Worthington v. Ahlers, 108 S.Ct. 963 (1988). The two-party cases usually involved cash contributions by old equity holders, see Matter of U.S. Truck Co., Inc., 47 Bankr. 932 (E.D.Mich. 1985); In re Marston Enterprises, Inc., 13 Bankr. 514 (Bankr. E.D.N.Y. 1981). These cases may be problematic under the wording of 11 U.S.C. $\S$ 1129 (b)(2). If old equity holders alone can make new cash contributions in return for new equity, the old equity holders may be receiving something on account of their old interest. Recent attention, however, has focused on the labor contribution case. See Norwest Bank Worthington v. Ahlers, 108 S.Ct. 963 (1988), rev'ing 794 F.2d 388 (8th Cir. 1986); Raymond T. Nimmer, Negotiated Bankruptcy Reorganization Plans: Absolute Priority and New Value 
gotiation problem in default and recapitalization. We then turn to the original question posed by Boyd, a freeze-out of an intermediate class. The freeze-out, we believe, is significantly more complex, and warrants reconsideration precisely because the rule implicates questions not just of contractual renegotiation but also of hierarchical capital structures and general agency problems. We go on to argue that even if Boyd embraces an idea that is sound in principle, the costs of implementing it are apt to dwarf any benefits it might bring.

We conclude with a look at a more complicated, but more realistic, case in which the senior class consists of those holding security interests in particular assets instead of a general, across the board, priority right to the assets and income stream of the firm. We address the question of when a secured creditor may claim some portion of the going-concern surplus, instead of just the collateral's liquidation value, to ensure that it receives "the value of [its] interest in the estate's interest in such property."24 Conventional wisdom holds that a secured creditor is entitled to the "going-concern" value of its collateral, whereas a foreclosure analogy would look to the collateral's liquidation value. Both of these views, however, accept a distinction between the liquidation and going-concern value that we propose to examine in detail to see whether and when such a distinction exists and when a secured creditor can claim one instead of the other.

\section{Renegotiation and Arbitration: The Two-Party Case}

In the two-party case, there is no unique renegotiation problem when the senior and junior owner actually reach a deal. Unlike the three-party case, only the failure to renegotiate triggers questions that implicate the absolute priority rule. Nonetheless, we start with the two-party case both because it introduces the general contours of the renegotiation problem without additional complexities, and because it has been the focus of the recent attention to the absolute priority rule.

When, following a default, a creditor renegotiates its original deal with the shareholders, the renegotiation raises familiar contractual questions. A renegotiation will occur only when the junior owner will receive less than its share, or nothing at all, in the event

Contributions, 36 Emory L.J. 1009 (1987). The seminal case that views the two-party case as the paradigm for the absolute priority rule is Case v. Los Angeles Lumber Products Co., 308 U.S. 106 (1939).

${ }^{24} 11$ U.S.C. $\S 1129(\mathrm{~b})(2)(\mathrm{A})(\mathrm{i})(\mathrm{II})$. 
of a distribution, but has something it can bargain with. The ability of a junior owner to bargain can derive from two sources. The junior owner may have power that is a result of the renegotiation rules themselves. For example, a shareholder might have the right to insist on elaborate valuation procedures when a firm is reorganized. This right, like others, can be waived, and it will be in the interest of all the owners to bargain for such a waiver when the value of these procedures is less to the junior owners than what they cost everyone else. Bargaining of this sort is, at best, a necessary cost of the renegotiation rules. ${ }^{25}$ Unless the procedural rights are themselves a good way of vindicating the initial bargain among the owners of the firm, we could well live without such bargaining.

The junior owner's ability to bargain may also derive from a different source. The junior owner may have something to contribute to the firm's future. An equity owner may be the manager of a firm who is better able to run it than anyone else. ${ }^{26}$ Alternatively, an old shareholder may be the one who is willing to contribute additional capital. ${ }^{27}$ Because she may have better information about the firm than others, she may be willing to add new capital when others are not. ${ }^{28}$ In these and other cases, the junior owner may have the power to renegotiate her original priority position.

Whether she also has the right to do so turns in large part on what the preexisting deal was respecting the ongoing and future contributions to the firm. In other words, one first has to determine whether de novo negotiation or renegotiation should take place. If there was no commitment respecting the supplying of fu-

${ }^{25}$ See Baird, 15 J.Legal Stud. at 144-45 (cited in note 10).

${ }^{26}$ The Supreme Court held in Case v. Los Angeles Lumber Products Co., 308 U.S. at 122 , that this expertise could not justify the continued participation of a junior class: "Such items are illustrative of a host of intangibles which, if recognized as adequate consideration for issuance of stock to valueless junior interests, would serve as easy evasions of the principle of full or absolute priority of Northern Pacific Ry. Co. v. Boyd." Three caveats about Case should be noted, however. First, it involved a dispute in which a junior owner wanted to participate over the objection of the senior owner. There was no agreement between a senior owner, otherwise entitled to all the assets of the firm, and a junior owner who wanted to freeze out an intermediate owner. Second, Case involved the participation of the entire class of junior owners, only some of whom had skills of value to the firm. Arguably, a different situation exists when only those with these skills in the group of junior owners are allowed to participate in the reorganized firm. Finally, the conflict that arose in Case is itself less likely to arise under the Bankruptcy Code because the absolute priority rule can now be invoked only if an entire class, not simply a single creditor, dissents from the plan of reorganization.

${ }_{27}$ See, e.g., Kansas City Ry. v. Cent. Union Tr. Co., 271 U.S. 445 (1926).

${ }^{28}$ Others with ownership claims to the firm may likewise have something to contribute to the firm's future, and hence have bargaining power. We deal briefly in Part II with the renegotiation powers of intermediate owners. 
ture inputs, then any negotiation over them is permissible, as a matter of de novo contracting. But, the owner may already have committed to supply such inputs in the future. In those cases, while she may not have the right to renegotiate, she may have the power. In a world in which legal relief is less than perfect, a junior member could renegotiate her original entitlement by threatening to withhold that which she was already obliged to provide.

Ordinary rules of contract set limits on the ability of one party to a contract to renegotiate terms after the contract has been entered into. We can imagine cases in which someone with firm-specific expertise, for example, the ability to complete a half-written software program, would try to renegotiate her original deal even if the firm were not reorganizing and even if she had no ownership interest in the firm. Firm has given $\$ 100,000$ to the programmer and the programmer insists that she be paid an additional $\$ 50,000$. As long as the damage remedy for breach of contract is undercompensatory, rules that limit renegotiation under these circumstances may check opportunistic behavior. ${ }^{29}$ The senior creditor, like any other party facing such opportunistic renegotiations, can avail itself of those rules.

In the absence of rules that limit the ability of parties to behave opportunistically, the firm must adopt a strategy to check such behavior. If the senior creditor fails to strike a deal and if the programmer makes good on her threat, everyone will be worse off. The half-completed program may never be finished. On the other hand, if it negotiates, the senior creditor may invite others to engage in the same kind of behavior in the future. A strategy of never negotiating with terrorists may be the most effective.

In the ordinary two-party case that does not involve a financial reorganization of the firm's capital structure, the renegotiation rules have an important characteristic. Ordinary contract law never imposes binding arbitration on parties in lieu of bargaining. No mechanism compels the firm to accept a compromise when the other party to the contract wants to renegotiate the original deal.

The crucial question for us is whether and how the rules governing the senior creditor's response to renegotiation requests from a junior owner following default should differ from those that prevail under other circumstances. Because bankruptcy is a collective proceeding, the bankruptcy judge has the power in some cases to

${ }^{29}$ See Austin Instrument v. Loral Corp., 29 N.Y.2d 124, 324 N.Y.S.2d 22, 272 N.E.2d 533 (1971); Alaska Packers' Ass'n v. Domenico, 117 F. 99 (9th Cir. 1902); Richard A. Posner, Economic Analysis of Law $\S 4.2$ 87-88 (3d ed. 1986). 
bind nonconsenting parties. Without such a power, there would be no way to overcome the collective action problem that is the justification for bankruptcy in the first instance. ${ }^{30}$ But it by no means follows that this power to bind nonconsenting parties should be used when a junior party seeks to renegotiate its original deal, inside of bankruptcy, without the consent of those senior to it. ${ }^{31}$ Whether the basic renegotiation rules should remain the same in restructuring the firm's financial structure is the subject we address in this part of this paper.

Firm designs computer software. Firm is worth $\$ 135$ if it defaults and its assets are broken up and sold to a third party. ${ }^{32}$ The owner-manager (Manager), however, has a set of firm-specific skills. If Manager continues to run Firm, it is worth $\$ 150$. It is the value added by the entrepreneurial skills of Manager, or $\$ 15$, that in this example might be lost if there were a sale to a third party. Hence it is this amount that must be considered the "going-concern surplus" that the law of corporate reorganizations tries to preserve. $^{33}$

Under Manager's direction, Firm can continue its efforts to develop its software program. If successful, Firm will be sold in a

${ }^{30}$ See Jackson, Logic and Limits at ch. 1 (cited in note 10).

31 Conventional bankruptcy doctrine suggests that cases that are simply two-party disputes are inappropriate for bankruptcy. See, e.g., In re Tinti Construction Co., 29 Bankr. 971 (Bankr.E.D.Wis. 1983). Many of the cases in which a petition is dismissed for "bad faith" are cases in which the debtor has only a single secured creditor. See, e.g., Matter of Little Creek Development Co., 779 F.2d 1068 (5th Cir. 1986); In re Thirtieth Place Inc., 30 Bankr. 503 (Bankr.App.9th Cir. 1983).

${ }^{32}$ We are assuming that the third party has no ability to appreciate the entrepreneurial skill that makes Firm worth more when Manager is running it. Informational asymmetries prevent a third party from recognizing the value of the participation of Manager. The assets that can be sold to a third party include intangible assets. The only "asset" that cannot be sold is the entrepreneurial skills of Manager. For that, a deal must be struck with Manager. If there is no informational asymmetry, then the buyer will calculate how much it will have to pay Manager to continue working, and the buyer would be willing to pay up to $\$ 150$ minus that amount for the assets. In that case, there is no worry about a socially desirable allocation of assets. We would face only the question of whether cutting off the tail would be appropriate. But that issue is inherently a three-party issue concerning omission of an intermediate class. In the two-party case, if there is no informational asymmetry, the same result will be reached irrespective of what anyone does.

${ }^{33}$ In this paper, we embrace the idea, which we have developed elsewhere, that the going-concern surplus is not the value of the firm as a unit as opposed to its value if sold off piece by piece but rather the difference between the value that can be raised when sold to third party and the value if left in hands of the existing owners. See Douglas G. Baird and Thomas H. Jackson, Corporate Reorganizations and the Treatment of Diverse Ownership Interests: A Comment on Adequate Protection of Secured Creditors in Bankruptcy, 51 U.Chi.L.Rev. 97 (1984). We believe this value lies largely in the entrepreneurial skills of the existing equity holders. If there are no such skills, then the liquidation value of $\$ 135$ would equal the continuation value. 
year's time for $\$ 200$. If the venture fails, Firm's assets will again be sold in a year's time, but they will bring only $\$ 100$. Success or failure is equally likely. ${ }^{34}$ The wage Manager is paid during the course of the year equals the wage she can command in the market exclusive of her firm-specific skills. As Firm is currently set up, compensation to Manager for her firm-specific skills is entirely in the form of equity participation in Firm. ${ }^{35}$ If Manager loses her equity interest, she becomes indifferent about working for Firm or someone else. ${ }^{36}$ We assume that Manager has the power, if not the right, to refuse to work for Firm and work for someone else.

We look at several variations on this common set of facts. In the first, we shall assume that Firm has only a single creditor (Bank), that it owes Bank $\$ 150$, and that the loan is in default. ${ }^{37}$ Firm is in fact worth $\$ 150$ if its assets are put to their best use, and the default gives Bank the right to all the assets of Firm. But two obstacles may prevent Bank from realizing Firm's full value. First, Bank may not be able to convince any third party that Firm is worth $\$ 150$. Second, even though Manager has already been compensated for her firm-specific skills, anyone who acquired Firm may have to let Manager retain all or part of her equity interest or increase her compensation in some other way in order to keep her working.

${ }^{34}$ We assume risk neutrality. Our example has a dichotomous outcome. The more typical case, of course, involves a variety of possible outcomes, each with a probability attached to it. In those cases, the possibility of a "tail" is more evident. But the same discussion can be generated from our simple example, which we use for expositional purposes. We use a discount rate of zero in the example to keep the numbers simple. The use of a more realistic discount rate would not affect the analysis.

${ }^{35}$ In the three-party cases, where the baseline position of Manager vis-a-vis the general creditors may matter, we will examine other forms of compensation to Manager. In the twoparty cases, however, the assumption permits us to focus the inquiry. Even so, the equity interest could have arisen from an initial cash contribution, from contribution of an original idea or product, or from stock options and the like. But if the equity interest arose from sources other than Manager's entrepreneurial skills, we would not see Bank wanting to recombine with the old equity holder. We are not concerned in this paper with the participation of the old managers while a new buyer is being sought. Money paid for their cooperation over the short term is not the same as compensating them for entrepreneurial skills over the long term.

${ }^{36}$ Her salary is based on non-firm-specific skills, and hence would be the same at Firm or elsewhere.

${ }^{37}$ If a firm has only a single creditor, it makes no difference whether the loan is secured or unsecured. Only the procedures whereby the creditor vindicates its rights will be different. When we look at the three-party case, however, we may have to focus more precisely on the rights of a secured creditor vis-a-vis an unsecured creditor. For being a secured creditor on a firm's assets may not be identical to being a senior creditor on anything the firm generates. But since creditors are senior to equity interests on anything a firm generates, this complication is irrelevant in the two-party case. 
If Bank simply waived its right to force a sale of Firm, the value to it of Firm as a going concern would be only $\$ 125$. (There is a 50 percent chance that Firm will flourish and Bank will be paid the $\$ 150$ it is owed; there is also a 50 percent chance that the venture will fail and Bank will recover only $\$ 100$.) The value of Firm to Manager is $\$ 25$. (There is a 50 percent chance that Firm will be worth $\$ 200$ and $\$ 50$ will be left after Bank is paid, and a 50 percent chance Firm will be worth only $\$ 100$ and nothing will be left for Manager.) Under these conditions, however, Bank will not sit still. Bank has an incentive to exercise its default right, force the sale of Firm, and recover $\$ 135$.

If Bank were limited either to waiving its default right or liquidating Firm, it would choose the latter course. Bank will not allow the Firm to continue in the absence of a new deal. ${ }^{38}$ Bank will get $\$ 10$ more by exercising its default rights than by permitting Firm to continue as before. Bank will not be able to bid the value of its claim against Firm at the foreclosure sale, keep Firm intact, and enjoy its entire future income stream unless Manager continues to work for Firm. And, following a foreclosure sale in which equity is wiped out, Manager has no incentive to continue working for Firm in the absence of a new deal. Renegotiation therefore makes sense in this case. Bank and Manager together ought to be able to negotiate a deal that makes them both better off. ${ }^{39}$ Because Firm is worth more as a going concern than if liquidated, it is in the interest of both parties to reach a compromise, in which Bank receives something worth more than $\$ 135$ and less than $\$ 150$, and where Manager receives something more than $\$ 0$ and less than $\$ 15 .^{40}$ In the typical renegotiation, Manager will give Bank a personal guarantee or contribute additional capital to Firm in return

${ }^{38}$ A legal rule might require Bank to sit still. The question we are examining, however, is the merits of precisely such a rule, the absolute priority rule as interpreted by Ahlers. To do so, it is useful to see the dynamics of the relationship in the absence of an intervening trumping rule.

39 There is $\$ 15$ to gain by continuation over liquidation. If Firm liquidates, Bank gains $\$ 10$ (over continuation) but Manager loses $\$ 25$. Thus, there is a going-concern surplus of $\$ 15$ that will be lost if (as we are assuming from the assumption of informational asymmetry) Manager cannot find new employment that replaces that $\$ 15$.

10 We assume either that Manager had not previously contracted to work for Firm, and hence had the privilege of leaving (a de novo renegotiation case), or had previously contracted but could leave in spite of the contract because Bank could not cost-effectively pursue contract remedies. If Manager had previously contracted to provide services, had no "unforeseen circumstances" reason to support renegotiation, and if Bank had effective legal remedies, Bank would not agree to the renegotiation. Under these circumstances, we see no reason why a bankruptcy court would provide a different answer. 
for Bank's waiver of its default right."1

As a result of issuing the guarantee or contributing new capital, Manager's interest in Firm, net of the new contribution, is now worth less than $\$ 25$, the value of her interest if Bank had no default right. ${ }^{42}$ But Manager's interest is worth more than $\$ 0$, the value of her interest if Bank had exercised its default right. Similarly, by giving up its default right, Bank must rely on the value of Firm as a going concern, but when the guarantee or the new capital contribution is taken into account, the value of this interest will now exceed $\$ 135$, the amount it would have realized if it had sold Firm to a third party.

To look at the case another way, when Firm defaults, Bank has an option to acquire the assets of Firm in return for its claim on Firm's income stream. ${ }^{43}$ Bank will want to exercise this option whenever the option is worth more than its claim on the income stream. If Manager wants to preserve the value of her firm-specific asset, which exists only if Bank does not close down Firm by taking the other assets away, she must buy the option from Bank.

Because Firm is worth more as a going concern, one would expect to see Bank and Manager reach some sort of deal whereby Firm would be continued and Bank and Manager would split the

41 If done as a formal two-step transaction-a foreclosure on the assets of the firm by the secured creditor followed by the establishment of a new firm where the assets are contributed by the secured creditor and the entrepreneurial skills by the old owner-managers-compensating the old owner-managers with an interest in the new firm may violate state law corporate rules prohibiting the issuance of stock for promises of labor in some states. See e.g., New York Business Corporation Law § 504(a); R. Clark, Corporate Law 710 (1986). This prohibition, however, is by no means uniform. See, e.g., Model Business Corporations Act I 504(a) (McKinney's); Robert Charles Clark, Corporate Law 710 (1986). This prohibition, however, is by no means uniform. See, e.g., Model Business Corporations Act $\S$ 6.21(b) (allowing the issuance of shares for contracts for future services).

The status of state law stock issuance rules is important. In states where stock cannot be issued for promises of labor or, presumably, for such things as expertise, the two-step transaction could not be structured so as to leave the old owner-managers with equity in the company. In those states, the rule of Boyd could be seen as a rule prohibiting through recapitalization or the like a similar outcome. As such, it functions as a rule that pierces through form, the "retention" of old stock, to substance, the effective issuance of new stock in a new company. Seen that way, however, in states where the issuance of shares for contracts for future services, or expertise, is permissible, there is no such prohibition on a twostep transaction, and the assertion for a prohibition on the recapitalization must then come from some other sources than form over substance. The text will assume that stock issuance for contractual promises to provide expertise is permissible, to focus more precisely on the absolute priority rule features of Boyd.

\$2 Given that Bank will not accept anything less than $\$ 10$ to waive its default right, Manager's interest will of course be worth less than $\$ 15$.

t3 See Fischer Black and Myron Scholes, The Pricing of Options and Corporate Liabilities, 81 J.Pol.Econ. 637 (1973). 
- \$15 going-concern surplus. Bank or Manager might not always reach a deal, of course, because of bargaining costs or because of different perceptions as to the values we assume here as a given. ${ }^{44}$ Alternatively, if Manager had previously contracted to provide the services and this restructuring was a species of contractual "holdup," Bank might not agree to a renegotiation in order to preserve a "no negotiation" policy in such situations to deter future occurrences.

If bargaining between Bank and Manager failed, and Bank exercised its option, the third party that bought Firm at the foreclosure sale might close Firm, if it were not as fully informed as Bank and Manager. Because it has less easy access to information about Firm, a third party may not know that Firm's assets in their present configuration, including Manager's expertise, are worth more than if deployed in some alternative use. Hence, the failure of Bank and Manager to reach a deal may result in a net social loss.

To the extent that it is cost-justified, parties should try to construct their initial agreement to prevent or minimize the costs that arise from bargaining after the fall. They should try to ensure that neither party would have the ability to exercise an option to withdraw an essential input from Firm, either the assets or the firm-specific skills, when it was not in the collective interest of all the owners.

Because the parties' efforts to prevent the bargaining failure will be imperfect, one might argue that a legal rule should respond to this potential bargaining failure. Indeed, one can argue that the existing debate over the absolute priority rule raises exactly this issue. The crux of this dispute is whether the old owner-manager should be able, in a bankruptcy proceeding, to retain her equity interest in the firm by contributing enough capital or other input to ensure that the creditor's interest in Firm as a going concern was at least equal to the amount it would be able to realize if it forced a sale of Firm's assets and took the proceeds.

The issue is whether Manager should be able, through resort to bankruptcy, to force a deal on Bank where Bank is given $\$ 135$ and where Manager retains the remaining value of Firm. This result avoids the possibility of bargaining impasse just noted, and does so by allocating the entire $\$ 15$ going-concern surplus to Manager. The wisdom of such a legal rule in cases in which only two parties are involved is the focus of the rest of this part of the

44 Informational asymmetries may exist between Bank and Manager as well as between those inside and outside. 
paper.

We argue that, notwithstanding the costs that everyone suffers if the bargaining breaks down, the bilateral negotiations that follow a default are useful. It seems most consistent with the likely initial bargain that when a default exists, Manager has the choice between paying Bank $\$ 150$ or giving it Firm. One cannot argue for a different characterization of the initial bargain on the ground that, but for the default, Manager would be entitled to the possibility that Firm would generate more than $\$ 150$ in the future. At the outset, Manager agreed to the conditions under which Bank could insist on selling Firm to a third party and therey collapsing future possibilities to present values, that is, liquidating Firm. Manager now has the choice between losing Firm or renegotiating the original deal. Manager can enjoy the profits of Firm only if Firm does not default.

This description of rights on default seems consistent with the initial bargain one typically sees. Moreover, it seems to be in the joint interest of Manager and Bank. First, Bank itself may not know that Firm is worth more in the hands of Manager. It may think that Firm should be closed. Manager's assertion that Firm is more valuable alive than dead is, after all, inherently suspicious. Because Manager will be left with nothing if Bank forecloses, it is in Manager's interest to keep Firm alive even if it is not in Bank's and Manager's joint interest.

The existence of the option right upon a default allows Bank to put Manager to the proof of her assertion that Firm is worth keeping intact. Bank may not be fully informed. Determining that Firm is better off proceeding with its venture than liquidating is likely to be difficult. Manager, who is most intimately familiar with Firm, may be better informed, but lacks the incentive to disclose what she knows. Firm has more value to her as a going concern than if liquidated even if that is not the case for all the owners of Firm as a group.

A contract term that required Manager to buy Bank's option on the assets of Firm as a way of avoiding the impact of a default may be a mechanism that forces Manager to reveal that the owners as a group (Bank and Manager) will be better off if Firm continues. Parties, accordingly, would bargain for Bank to have a default right even when Firm had value as a going concern if it provided a mechanism whereby Bank could learn that Firm had value as a going concern and that information was otherwise hidden.

The parties might find the right valuable even in cases in which it was in Bank's own interest to keep Firm intact, because 
one cannot identify ahead of time such cases with precision. To be sure, a case might arise in which it was in Bank's interest, even absent a financial restructuring, that Firm stayed intact, but Bank would still use its right to call a default to improve its position at Manager's expense. ${ }^{45}$ Bank's threat to exercise its default right brings the risk of a costly bargaining failure without any offsetting gain. But imposing a new bargain on Bank through arbitration or the like may not be a desirable solution to this problem. Once one introduces a resolution procedure, what will be presented to the arbitrator-or a bankruptcy judge-as a bilateral negotiation case might well involve a case where Bank does not believe Firm will be worth even $\$ 135$ in the hands of Manager. ${ }^{46}$ If Firm is not worth $\$ 135$, it should, of course, be liquidated, and it is not at all clear that a bankruptcy judge is better able to make this determination than Bank.

One might argue that this conclusion omits the costs of the bargaining process and their potential to lead to the failure of Firm as a going concern. One function of bankruptcy law, the response would continue, is to ensure that the failure of even a single creditor and a debtor to reach a bargain that made them both better off would not lead to dismembering a firm. Bankruptcy, under this view, is a form of binding arbitration that protects the value of the secured creditor's interest and ensures that firms that have a going-concern surplus stay in business.

This argument seems both normatively and descriptively wrong, however. Parties show no inclination to contract for an arbitration mechanism to prevent potentially destructive exercises of the default right, even if no transaction cost stood in their way. It seems unlikely, moreover, that parties fail to contract for the mechanism because they are relying on the presence of existing

45 Bank may be willing to do this, even when it is not in its interest in this particular deal, in order to establish its reputation as a "tough" negotiator for future cases. Whether it will work, of course, depends on an informational asymmetry concerning the value of Manager to Firm. In a default, that informational asymmetry is likely to exist: Bank is likely to have better information than third parties as to whether the default was due to lack of skill of Manager or to something else.

18 One can look to actual behavior to justify the conclusion that arbitration might not be in the parties' interest. If a rule regarding labor contributions as sufficient to satisfy the absolute priority rule were the proper off-the-rack rule, as the Eighth Circuit held, though recently reversed by the Supreme Court, Ahlers, 108 S.Ct. 963 (1988), rev'ing 794 F.2d 388 (8th Cir. 1986), one would expect to see clauses in loan contracts where Manager could buy Bank out at any time at the then-appraised value of Firm's assets on a sale to a third party. Such clauses do not, however, typically appear. Their absence supports the notion that the "put" analogy is proper. As such, any subsequent renegotiation is not an extraction by Bank, but a predictable pay-out, in Manager's favor, of the original deal. 
bankruptcy law to provide the off-the-rack rule. Quite apart from the inefficiencies of existing bankruptcy law relative to arbitration, under existing law, bankruptcy courts traditionally refuse to entertain a bankruptcy case involving a corporate debtor in which there was only a single creditor. ${ }^{47}$ Seen from this perspective, the result of the Supreme Court's opinion in Ahlers, that a junior owner cannot participate as of right in the reorganized firm by offering to contribute labor, seems consistent with the parties' initial bargain. ${ }^{48}$

A variation on these facts is worth discussing. Assume Bank is owed not $\$ 150$, but $\$ 300$. Because it will capture all the benefits if the new computer venture succeeds, Bank now prefers continuation to liquidation. ${ }^{49}$ Even though it has a default right, it has no reason to exercise it. Bank will already enjoy all of Firm's future earnings if it remains intact. It cannot extract anything from Manager by threatening to liquidate. In this case, however, Manager has no incentive to continue with the venture. Because she will get nothing even if Firm succeeds, she has no incentive to continue to offer her firm-specific skills to Firm.

Just as Bank may have the option to take the assets away and prevent Firm from engaging in a venture that is in the joint welfare of the parties under certain conditions, so too Manager may have the option to take her firm-specific skills away from Firm. Manager, however, unlike Bank, has nothing to gain by withdrawing from Firm. ${ }^{\text {so }}$ Leaving Firm would make Bank worse off without

${ }^{47}$ See Nimmer, 36 Emory L.J. at 1069 (cited in note 23); Comment, Good Faith Inquiries Under the Bankruptcy Code: Treating the Symptom, Not the Cause, 52 U.Chi.L.Rev. 795 (1985). Cases involving a debtor who is an individual are distinct, for in those cases bankruptcy's fresh-start policy provides relief for the debtor even from the demands of a single creditor. Ahlers is arguably close to that paradigm, as it involved a family farmer. But normally, the quid pro quo for the fresh start in Chapter 7 is that the debtor's existing assets are taken away. In Ahlers, the debtor wanted to keep his farm and get the discharge. At the time of Ahlers, such a possibility existed under Chapter 13, but constraints on its use probably led Ahlers to seek a similar result under Chapter 11. (Chapter 12 would now be an alternative approach for many family farmers.) But nothing in the Eighth Circuit's opinion in Ahlers was limited to the case of debtors who are individuals. We focus in this paper on the corporate case because it allows us to test the absolute priority rule freed from the effects of bankruptcy law's fresh-start policy for individuals.

${ }^{48}$ Indeed, any contribution, whether of labor or cash, that permitted the shareholders to retain an interest without the consent of the senior creditors would seem not to justify imposing a bargain where none in fact was reached. In that respect, the dicta in Case regarding cash contributions may be incorrect. Arguably, the Bankruptcy Code does not adopt the Case dicta although the Supreme Court in Ahlers did not reach that issue. See note 23.

49 Since it now gets all the upside (which, under our assumptions, is capped at $\$ 200$ ), it has an expected value from continuation of $\$ 150$, and a liquidation value of $\$ 135$.

so Our assumption is that because of informational assymetries Manager will entirely 
making her any better off. As long as Manager could make her threat to leave credible, however, we would expect the parties to bargain. Instead of the $\$ 150$ Bank would enjoy if Manager had no credible threat, Bank would, as a result of the threat, agree to live with a more modest package of rights worth between $\$ 135$ and $\$ 150 .{ }^{51}$ Exactly as before, the bargain would be over the $\$ 15$ goingconcern surplus.

In this case, however, Manager has nothing to gain from exercising her option to leave Firm except what she can gain in bargaining with Bank. Such a bargain does not increase the joint welfare of the parties. Indeed, such bargaining is costly. In the worst case, negotiations may break down and Manager may leave Firm, dramatically decreasing the joint welfare of the parties and creating a social loss.

Although a bargaining impasse might lead to a socially undesirable outcome, neither bankruptcy law nor the absolute priority rule seems an appropriate response to the problem. Bank should not gain the right to force Manager to work for Firm through bankruptcy law. ${ }^{62}$ Both with and without bankruptcy, Bank has the right to take over all the assets of Firm, other than those contributed by Manager in the form of future services. To gain the advantages of those services, Bank would need to point to an employment contract between Firm and Manager, and then to some effective way of enforcing that contract. But such a solution depends on the presence of an existing contract, not on the bankruptcy option. In short, the dispute between Bank and Manager should turn on the obligations of Manager to Firm, obligations that exist regardless of whether Firm has defaulted to one of its creditors.

A prophylactic rule prohibiting recombinations with Manager would, moreover, sweep too broadly, just as an arbitration rule in the last example sweeps too broadly. Given that, absent some renegotiation, Manager has no reason to continue to work for Firm, an

lose the $\$ 15$ of value attributable to her special expertise if Firm is liquidated.

s1 For example, Bank might agree to receive the entire value of Firm, $\$ 100$, if it fails in a year's time, and $\$ 170$ if it should succeed in a year's time. The remaining $\$ 30$ in the event of success, with a present value of $\$ 15$, would go to Manager.

${ }^{62}$ Courts traditionally are hostile to noncompetition covenants. See ABC v. Wolf, 52 N.Y.2d 394, 438 N.Y.S.2d 482, 420 N.E.2d 363 (1981). This skeptical view of noncompetition covenants is sometimes expressed by statute. See, e.g., Wisc.Stat. $\S 103.465$ (1988). Absent an employment agreement, Bank clearly will not be able to force Manager to continue to work for Firm. We discuss in Part II the ability of creditors to prevent Manager from engaging in a sham transaction to improve her position while still working for Firm. 
effective prohibition on renegotiations will lead, in many cases, to the departure of Manager and the dissolution of Firm. Moreover, policing against recombinations is extraordinarily difficult. If Manager cannot renegotiate so as to leave her with equity, she might try a renegotiation that leaves her with a larger future salary, and concomitantly less cash for Bank, or for a combination of a larger salary and options on Firm. These recombinations reach the same result, and would likewise have to be swept within the prohibitions of the prophylactic rule, to ensure that form did not prevail over substance.

A third case arises when Bank is owed $\$ 150$, but Firm can be liquidated for only $\$ 120$ instead of $\$ 135$. As in the second case, Bank is better off if Firm continues. (If Firm liquidates, Bank will receive $\$ 120$; if it continues, Bank will receive $\$ 125$.) But unlike the second case, Manager is actually worse off if Firm liquidates; she is not likely to be indifferent to the decision to liquidate. The parties would be better off if no bargaining between them were possible. Both parties would be worse off if they exercised their options to exit. For that reason, the third example, in many respects, is a more extreme version of the second. The possibility of bargaining introduces the possibility of brinkmanship on both sides and could result in some cases in a liquidation taking place that was in no one's interest.

Even in this case, however, it does not follow from the possibility of an undesirable bargaining breakdown that invocation of bankruptcy is appropriate. As before, one has to worry about whether bankruptcy can distinguish with sufficient accuracy cases where bargaining involves only brinkmanship from cases where there is a genuine dispute over the value of Firm as a going concern, and why, if such a distinction were generally possible, it would not be provided for by private agreement of the parties. Again, arbitration clauses are not generally used to overcome such bargaining impasses.

There is, moreover, an additional reason to permit the bargaining. Default rights, after all, exist for a reason. Bank uses its default right not simply to ensure that it can reach Firm's assets when Firm fails to pay it. Bank also depends upon the default right to monitor and control the behavior of Manager. Such monitoring is apt to be particularly important in the situations in which Firm is insolvent and Manager has powerful incentives to misbehave. The ability to call in assets upon a default is one way in which Bank monitors Manager. A legal rule that has the effect of limiting the Bank's ability to call a default may have the undesir- 
able side effect of limiting its ability to control debtor misbehavior.

\section{The Residual Senior Owner and the Freeze-out Problem}

In considering the absolute priority rule in the two-party case, accordingly, there is little reason to provide an override that will permit old owner-managers to keep a portion of the ownership interest in a reorganized firm without the consent of the senior class. ${ }^{.3}$ But this two-party example, where we assume only a senior and a junior class, is not the hardest case, nor was it Boyd's central concern. To focus on the issue raised by Boyd, we need to posit the case where there is an agreement between a senior class and the class of equity owners to a restructuring, but where an intervening class, such as a class of general creditors, objects. ${ }^{54}$

In this case, while one still has to make the distinction of the two-party case, de novo negotiation versus renegotiation, additional problems are introduced because, with multiple parties, identifying the person who will bargain with the junior owners becomes somewhat problematic. To argue, as a proponent of Boyd must, that the participation of the old shareholder is illegitimate, one must focus on the source of that shareholder's bargaining power. One must show first that the shareholder is bargaining over something that she has no legal right to withhold from the firm. If the old shareholder is entitled to withhold future services, or other inputs, from the firm, she is not acting qua preexisting shareholder at all, but simply as a supplier of a new input. In that capacity, the negotiations with the shareholder are but a species of a common problem of negotiation with a party who is both a prior owner and a future supplier. A major supplier may also be a preexisting creditor because it is owed for supplies it has previously shipped. If other sources of supply are not readily available, the supplier may be able to insist that past defaults be cured before additional deliveries begin. ${ }^{\mathrm{s5}}$ The firm's employees may also be creditors, hence

ss We do not address the change made in the 1978 Bankruptcy Code, permitting a class-wide vote to bind dissenting members of the class to an outcome otherwise proscribed by the absolute priority rule. See 11 U.S.C. $\S 1129(\mathrm{a})(8)$. The movement from a unanimity rule to a "majority" rule may be justified as a response to a collective-action problem and problems of hold-outs and disparate information. We assume unanimity within a class and examine, instead, inter-class conflicts.

${ }^{84}$ The objection may come because the intervening class thinks it has received too little. The conceptually cleanest case to examine is the case where the intervening class has received nothing, and that is the case we will focus on in the text.

${ }^{85}$ See, e.g., In re Ike Kempner \& Bros., Inc., 4 Bankr. 31 (Bankr.E.D.Ark. 1980) (refusal to supply shoes to retailer). See generally, In re Garnas, 38 Bankr. 221 (Bankr.D.N.D. 1984) 
owners, because of unpaid wages. They might strike unless they are paid in full, even though their priority position did not entitle them to payment in full. ${ }^{56}$ In all these cases, the junior owner may have the power to renegotiate its original position.

Second, when the shareholder cuts a deal with a senior creditor following a default, one must also establish that the intermediate creditor has the right to object to the firm's acquiescence in the shareholder's exercise of her bargaining position, even if it is illegitimate. The intermediate creditor must explain why, given that the senior creditor is owed more than the firm is worth, the senior creditor should not be entitled to negotiate on behalf of the firm.

We have addressed the first of these problems in the previous part of the paper. The more difficult issue is the second, raised by Boyd: identifying the person who is entitled to bind the firm when the firm is being restructured. In corporate law there is rarely an ambiguity about who is entitled to negotiate on behalf of the firm. As a general matter, the residual owner of the firm is entitled to negotiate on behalf of the firm. ${ }^{57}$ The residual owner is given the power to bind the firm because the residual owner stands to have the right set of incentives. The dollar that is won or lost because of good or bad negotiating by definition is felt by the residual owner. In a solvent firm, the shareholders are the residual owners, and the managers of the firm typically act with their interests in mind.

Identifying the residual owner, however, is more difficult in the cases in which the Boyd rule is likely to be invoked. The firm that is reorganizing is typically insolvent. In the case that we focus on throughout this paper, if all future possibilities were collapsed to present values, the senior creditor would be entitled to the entire firm. In this sense, the senior creditor is the residual owner of the firm. But, in the absence of a default; everyone's ownership interest has value. There is always a possibility that the firm's assets will be worth more-and its liabilities less-than expected. That possibility makes the reorganization case different from the

(refusal to renew an insurance policy); In re Blackwelder Furniture Co., Inc., 7 Bankr. 328 (Bankr.W.D.N.C. 1980) (refusal to continue to ship supplies).

so See, e.g., Matter of EDC Holding Co., 676 F.2d 945 (7th Cir. 1982).

${ }^{87}$ See Frank H. Easterbrook and Daniel R. Fischel, Voting in Corporate Law, 26 J.L. \& Econ. 395, 402-06 (1983); Eugene F. Fama and Michael C. Jensen, Agency Problems and Residual Claims, 26 J.L. \& Econ. 327, 331-32 (1983). In this paper, we largely collapse the manager with the equityowners, although legally "neither officers nor directors are agents of the shareholders." Robert C. Clark, Agency Costs Versus Fiduciary Duties, in John W. Pratt and Richard J. Zeckhauser, eds., Principals and Agents: The Structure of Business 55, 56 (1985). 
typical solvent firm in which the residual owners are the shareholders and the shareholders are the decision makers.

Bargaining after the fall should be conducted by the residual owner of the firm, even if in the original capital structure others are junior to it..8 Even if the freeze-out problem were a genuine one-that junior owners were able because of valuation problems or any other reason to retain their ownership interests at the expense of those senior to them-the rule in Boyd is exceedingly unlikely to be worth the costs that necessarily accompany it. The solution to bankruptcy's bargaining problems lies elsewhere.

\section{A. Collusion and Valuation}

Before addressing the problems of renegotiation in the multiparty case, we want to raise two different defenses of the rule of Boyd that we think are insufficient to justify its existence. The first is a worry of collusion. The intermediate owners might fear collusion between the most senior owners and the most junior ones. The senior creditors have the right to collapse future possibilities to present values only when a default exists. The intermediate creditors might fear that a junior owner might create the condition that triggered the exercise of the default right in return for a subsequent interest in the firm. The junior owner might be better off without the intermediate creditor after a default than she would be with the intermediate creditor before the default. The intermediate creditor does not control the definition of a default between the firm and senior owner, that being a matter of contract between the two parties. Nor is the intermediate creditor well positioned to keep the firm from triggering a default. Hence, it might seem that the senior and junior owners could collude and restructure the firm at the intermediate creditor's expense.

Without ruling out collusion as a theoretical problem, it does not seem to be much of a practical problem. The freeze out of the intermediate creditor can take place only when the value of the firm is less than what the senior creditor is owed. One suspects that few cases arise in which both this condition holds and the sen-

${ }^{58}$ Nonbankruptcy law recognizes that such a shift should occur upon insolvency. See, e.g., Federal Deposit Ins. Corp. v. Sea Pines Co., 692 F.2d 973, 976-77 (4th Cir. 1982) (" $[W]$ hen the corporation becomes insolvent, the fiduciary duty of the directors shifts from the stockholders to the creditors"); In re Calton Crescent, 173 F.2d 944, 951 (2d Cir. 1949) (L. Hand dissenting) ("The books are full of declarations that an insolvent holds his property in trust for his creditors;" hence directors of a corporation become fiduciaries of the creditors upon its insolvency). 
ior creditor does not already enjoy a default right. Even in such cases, it seems to us counterintuitive that senior and junior owners would collude and the junior owner would agree to bring on a default. A default has many collateral consequences for the junior owner, all of them bad. In only the most unusual case will default make the junior owner better off, even if she can eliminate a class of creditors in the process.

The second worry, valuation, likewise strikes us as appropriate in the abstract, but unpersuasive as a defense of Boyd in a world in which creditors can resort to bankruptcy and can reinstate the agreements of senior claimants pursuant to $\S 1124$ (2) of the Bankruptcy Code. Valuations are difficult. We have assumed a sharp dichotomy in the possible values of the firm. Either the firm was worth more than the most senior creditor was owed, in which case the senior creditor would be paid in full and the intermediate creditors would become the residual owners of the firm, or the firm was worth less than what the senior creditor was owed, in which case the intermediate creditors are not the residual owners and hence have nothing to complain about. But the value of the firm may not be clear and we may not know who the residual claimant is. This ambiguity may lead to an additional concern that is distinct from and more troubling than the possibility of collusion between the senior and junior owners.

If an informational asymmetry prevents third parties from accurately assessing the value of the firm, the secured creditor may be the high bidder at the foreclosure sale even when the firm is in fact worth more than its claim. The intermediate creditors may be the residual owners of the firm in that they may value it at more than the senior creditor is owed, but still not be able to outbid the senior creditor. The intermediate creditors are frequently diverse. It is the collective action problem among the intermediate creditors that justifies a bankruptcy in the first instance. Even if they all thought the firm was worth more than the secured creditor was owed, they might not be able to join in a bid, and their individual interests may be so small that it is not in the interest of any one of them to bid. Difficulties associated with gathering information about the value of the firm and with raising capital may prevent them from paying the senior creditor the face amount of its claim.

The default by the junior owner allows the senior creditor to insist on recovering its capital contribution. Even though it is unlikely that the junior owner will provoke a default in order to freeze out the intermediate creditors, the default may arise not because the firm is worth less than what the senior creditor is owed, 
but because the junior owner's interest has become so small that she lacks the incentive to prevent the default from arising. The intermediate creditors, whose residual interest is worth more, might have prevented the default if they could have acted collectively. While the intermediate creditors can trust the junior owners to act in their interest when the firm is healthy, the same does not hold when it is in trouble.

In short, the mechanism of default and foreclosure does not protect the intermediate creditors from losing the firm when they are the residual owners. ${ }^{59}$ But the Boyd rule seems an inappropriate response to this problem. At the very least, it covers only part of the problem, for the problem of senior creditors taking the firm when they are not the residual owners arises even if there is no need for the renegotiations that give rise to the rule in Boyd. More important, doubts about whether a senior creditor is the residual owner should not lead one to limit its ability to engage in negotiations that are potentially in the interests of the firm.

The focus should be on making it easier for the intermediate creditors to discover the value of their rights and assert them rather than on making it harder for the senior creditor to exercise its rights of ownership. The problem is one of identifying the residual owner. In this sense, Boyd cuts too broadly as well as too narrowly. While it restricts only those senior owners who must renegotiate, it also restricts all such owners and draws no distinction between those who are residual owners and those who are not. But even among the small group that is properly picked up by the rule, Boyd seems badly designed if it is to insure that intermediate creditors who are residual owners are not bereft of control. Rather than giving them control or trying to establish whether they are the residual owners, Boyd simply inserts them into the negotiations.

The task of identifying the residual owner of the firm and putting that person in control is remitted to other parts of the Bankruptcy Code. The bankruptcy court cannot approve a plan of reorganization over the objection of the intermediate creditors without finding that the senior creditor is being paid no more than the value of its claim. ${ }^{60}$ Moreover, the intermediate creditors them-

68 The intermediate creditors can lose control when they would be the residual owner even if the senior creditor is enjoying no windfall. The senior creditor that must liquidate Firm may be able to realize less than it is owed, while the intermediate creditors might be able to keep Firm intact and still pay off the senior creditor. The value of Firm's assets (in a world with transaction costs) may turn on who owns them.

${ }^{60} 11$ U.S.C. $\S 1129$ (b); 124 Cong.Rec. 32408 (Sept. 28, 1978). 
selves can propose a competing plan of reorganization. ${ }^{61}$ In that plan, they can choose either to give the senior creditor the value of its claim or they can reinstate the old loan under its old terms. ${ }^{62}$

As this last alternative indicates, the Bankruptcy Code allows the clock to be turned back. The intermediate creditors can cure past defaults and restore the relationship between the firm and the senior creditor to its status before the default. If the intermediate creditors are indeed the residual claimants of the firm, they should be able to cure past defaults to the senior creditor and reinstate the old loan or, alternatively, propose a new stream of payments that gives the senior creditor the value of its claim. It is only when they are unable (or, more precisely, found by the bankruptcy judge to be unable) to take either of these routes that the senior creditor will be able to freeze them out.

The Boyd rule today must be viewed in the context of the existing Bankruptcy Code. When intermediate creditors are the residual owners but cannot act together collectively under ordinary nonbankruptcy rules, bankruptcy provides them with a mechanism for acting collectively and reinstating the senior creditor's loan. ${ }^{63}$ In these cases, the rule of Boyd is unnecessary. It applies only when the intermediate creditors, acting collectively, are unwilling or unable either to cure past defaults or pay the senior creditor the face amount of its claim. The existing Bankruptcy Code puts the intermediate creditors to their proof when they claim that the firm in their hands is worth more than the senior creditor is owed or that the default asserted by the senior creditor was attributable not to the conditions that the firm finds itself in, but to the negligence or collusion of the managers. Given the response of the Bankruptcy Code to the valuation issues raised in identifying the residual class upon default, the proponents of Boyd must look to something other than the difficulties associated with valuation for a justification for the rule's continued existence.

We do not pretend that existing bankruptcy law would be perfect without Boyd. The Bankruptcy Code pays too little attention to ensuring that the residual claimants are in control of the firm. Even though the intermediate creditors or the senior creditor will

6111 U.S.C. $\$ 1121$ (c) (permitting creditors to file a plan, after an exclusive period for the debt or in possession).

${ }^{62} 11$ U.S.C. $\S 1124(2)$. Reinstatement calls off that class' ability to invoke the absolute priority rule. 11 U.S.C. $\S 1129$ (a)(8)(B).

${ }^{63}$ This procedure could be incorporated in Chapter 7 as well to permit a sale mechanism while solving the collective action problem that otherwise impedes the ability of the creditors to act jointly in bidding. 
be the residual owners of Firm in the overwhelming majority of cases in Chapter 11, the Bankruptcy Code puts control of both the day-to-day operations of the firm and the plan of reorganization in the hands of the old managers of the firm, whose original loyalties lie with the shareholders. The Bankruptcy Code also eschews marketplace valuations. Intermediate creditors and others, when they are very unlikely to be the residual owners, may have too much power to force valuations and invoke procedures that are costly and ineffective.

Reform of the bankruptcy law should focus on the problem of residual ownership. A rule like Boyd that is not at all focused on this problem can be criticized on those grounds. Boyd does little to ensure that the intermediate creditors control the reorganization if, but only if, they are the residual owners. Boyd applies whenever renegotiations take place. It ignores those cases in which intermediate creditors are the residual claimants, but there is no need for renegotiations. It applies to all renegotiations, regardless of whether there is any ambiguity about who the residual owner is. Ambiguity about the identity of the residual owner and the need to engage in renegotiations only loosely correlate, if they correlate at all. In this paper, we show that once one can identify the residual owner of the firm, the ordinary rule that the residual owner should be able to bargain on behalf of the firm should hold inside of bankruptcy as it does outside. ${ }^{64}$

64 The problem of preexisting claimants also being suppliers of future goods or services complicates the proposal recently put forth in Lucian Arye Bebchuk, A New Approach to Corporate Reorganizations, 101 Harv.L.Rev. 775 (1988). There, focusing on the preexisting status of claimants, Professor Bebchuk suggests the issuance of a series of options to various classes, to avoid the strategic manipulations arising out of negotiations in the Chapter 11 framework. But while this proposal works as outlined in his piece when one limits one's focus to the owners qua owners (and assuming their claims can be fixed with some precision), it cannot solve the problem of deciding whether and how much should be given to junior owners in their capacity as suppliers of future goods and services. To resolve that question, one first must decide on who has the power to conduct such negotiations, and then how to deal with objections from classes that feel that too much has been given to junior groups. Even in the two-party case, one needs a rule to decide how to allocate (to use our example at notes $32-36$ ) the $\$ 15$ going-concern surplus. If we are right that the appropriate rule leaves this to bargaining, nothing in a move to an option model truncates, or should truncate, that bargaining. The same difficulty confronts the three-party case. Even if a rejection of the doctrine of Boyd is folded into Professor Bebchuk's model, negotiations between senior and junior classes are necessary whenever a junior owner is also a post-petition supplier of new inputs. And, before these negotiations can be carried on, one needs to decide who can conduct them. This requires a valuation of the entire firm, to decide the residual owner, prior to deciding who can propose the plan of reorganization, and the options. But as nonmarketplace valuation is the perceived problem with the reorganization process, once one introduces the problem of existing owners as future suppliers, one also sees that even 


\section{B. Negotiations and the Problem of Residual Owners}

We now consider other justifications for Boyd by returning to our original example, in which Firm's assets can be sold for only $\$ 135$, but with the firm-specific skills of Manager, Firm is worth $\$ 150$ because in a year it will be worth either $\$ 200$ or $\$ 100$ with equal likelihood. We shall again assume that Firm is in default to Bank which has a perfected security interest in all the assets of Firm. ${ }^{\text {Bs }}$ In addition, however, assume now that Firm owes Creditor $\$ 40 .{ }^{68}$

The central case that we are interested in arises when Bank is owed $\$ 150$. The introduction of the intervening class of Creditor makes this case different from the example in the previous part in which Bank was owed $\$ 150$. Bank, as before, wants to liquidate Firm. Even though Firm is worth more as a going concern from the point of view of all the owners as a group, it is not worth more from the point of view of Bank. The value of Firm to it as a going concern is only $\$ 125$, while it will realize $\$ 135$ if it sells Firm to some third party.

In this case, however, Manager will not be able to pay Bank enough to maintain the status quo. Because Manager only has a right to the assets of Firm, or the returns from it, after Creditor is paid, the present value of her interest if the status quo is preserved is only $\$ 5 .^{67}$ Manager will not find it in her interest to pay more than $\$ 5$, but Bank will not give up its option to liquidate for anything less than $\$ 10$. The desirable outcome for the owners as a group, however, is the same as before: Firm is worth more as a going concern than liquidated. The negotiations are now complicated, because it is a three-party negotiation over how to split the

the innovative option proposal cannot eliminate the firm valuation problem that is core feature of the Chapter 11 process.

6s For purposes of this discussion, we assume that having a security interest in all the assets of Firm is tantamount to having a senior claim to anything generated by Firm as well. In Part IV, we look at the complication introduced by the situation where the secured creditor is secured only by specific assets, and does not enjoy a blanket priority over others to all the assets of the firm and the income they generate.

${ }^{68}$ In the typical case, there will be many trade creditors and a resulting collective action problem that will make it difficult to reach a single agreement with all of them. We start, however, with a case where each "class" is represented by a single entity, to focus on the Boyd question without the additional complication of a collective action problem within a class.

${ }^{87}$ There is a $50-50$ chance that Firm will be worth $\$ 200$ in a year and in that event Manager will receive $\$ 10$, after Bank is paid $\$ 150$ and Creditor is paid $\$ 40$. There is also a 50-50 chance that Firm will be worth $\$ 100$ in a year, and in that event Manager will receive nothing. 
$\$ 15$ going-concern surplus.

In the absence of a way to freeze one of the parties out, bargaining among the three is essential. Bank's cooperation is needed, for if it is not obtained, Bank can liquidate its collateral. Bank would receive $\$ 135$, and Creditor and Manager would receive nothing, even though Firm is worth $\$ 150$. The cooperation of Creditor is needed, both to ensure that Bank's cooperation is achieved (because, to give Bank a package of rights worth in excess of $\$ 135$ not to foreclose, some of the value must come from the rights of Creditor), and because, without that cooperation, the deal between Bank and Manager is not possible. The cooperation of Manager is needed, for Manager has firm-specific skills and, in the absence of some additional compensation, she has no incentive to exploit them once her equity interest in Firm is wiped out.

Bank and Manager may, however, be able to avoid the complication of this three-party negotiation by a device that returns them to the two-party negotiation case we already examined. An alternative to liquidation or a multi-party negotiation is for Bank to foreclose on the property of Firm, acquiring it at a public foreclosure sale for $\$ 135$, and then to rehire Manager, at a price which replicates the negotiations over how to split the $\$ 15$ going-concern surplus we have already examined.

The effect of this transaction is to reduce the value of Creditor's interest to $\$ 0$. The question we want to ask is whether in cases such as this Bank and Manager should be able to freeze out the position of Creditor. ${ }^{68}$ Another way to ask the same question is whether, as the residual owner, Bank should be able to control the restructuring of Firm, even though Creditor's interest in Firm before the restructuring has value.

Note that the question is not whether a financial restructuring should take place. A restructuring is needed to prevent the closing of Firm. The question rather is whether a financial restructuring that involves the squeezing out of Creditor is permissible. ${ }^{69} \mathrm{Credi}$ -

${ }^{68}$ The freeze out will not work in any case in which the value of the assets of Firm, other than the expertise of Manager, is in excess of the amounts owing to Bank. In that case, the foreclosure would not freeze the general creditors out. Thus, the situations in which the general creditors would have to fear freeze out, and hence demand compensation for its possibility, are cases in which the liquidation value of Firm is less than the face amount of Firm's secured obligations.

${ }^{68}$ If it were in the joint interests of the parties, then, in effect, Manager and Bank would be giving Creditor a higher rate of interest to compensate it for the risk of being frozen out. As long as Creditor is compensated before the fact, the freeze out makes Manager and Bank better off without making Creditor worse off than it would have been had the freeze out not taken place. As a result, one has to look elsewhere to decide whether to per- 
tor argues that the squeeze out is impermissible because Manager has already exchanged her firm-specific expertise for the equity she initially received. Creditor argues that Manager must obtain its consent before she can renegotiate her compensation package. Because Manager's firm-specific skills are now an asset of Firm, ${ }^{70}$ Creditor's right to them is superior to Manager's.

To prevail, Creditor must show two things. First, it must show that the negotiations are over an asset to which it already has a superior claim because the asset belongs to Firm and its rights to Firm are superior to Manager's. In other words, it must show that, because of the deal Manager has struck with the Firm, her firmspecific skills belong to Firm rather than to her. Once Creditor establishes this point, it must also establish another. Creditor must show why, given that its own priority position is inferior to Bank's and that Bank is the residual owner, Bank should not be able to control the disposition of any asset of Firm as it chooses. Creditor must confront the argument that whether the asset (Manager's firm-specific skill) belongs to Firm or must be reacquired through negotiations should be a decision the residual owner of Firm is entitled to make, just as it is entitled to make all other decisions about Firm.

An example illustrates the problems Creditor might have in making its first argument, that Manager's firm-specific skills are an asset of Firm. Firm promises Manager a substantial amount of money in return for a completed software program that Manager agrees to develop for Firm. To take the clearest case, assume that at the time Firm reorganizes, the contract is entirely executory: Manager has performed none of the work and Firm has made no payments. Even though Manager, because of her right to be paid upon completion of the software program, is a contingent creditor, and hence an owner, of Firm, Manager's position cannot be analyzed as that of a typical nonexecutory creditor.

In an executory contract, the obligation of one party to perform is generally conditioned upon a continued belief that the performance by the other party will be forthcoming. ${ }^{21}$ In our example, Manager did not agree to perform even if it turned out that her

mit or prohibit such a freeze out as a matter of original entitlements.

70 Manager may have the right to leave Firm's employ (as there is no employment contract), but Manager, if she works for Firm, has already established the terms on which she works. It is in this limited sense that her firm-specific skills are an asset of Firm's.

${ }^{71}$ U.C.C. $\$ \S 2-609,2-610$ (1978). See, e.g., Oloffson v. Coomer, 11 Ill.App.3d 918, 296 N.E.2d 871 (1973). 
ownership interest was worthless, as her promise to perform was contingent upon performance by Firm. In this example, where contract law governs, not even Firm itself can complain about Manager's insistence on compliance with the original deal ${ }^{72}$ or a substitute therefore, such as an equity position. ${ }^{73}$ If Manager became reasonably insecure about Firm's performance in cases where Firm was solvent, Firm would have to assure Manager that the original quid pro quo would be forthcoming or otherwise renegotiate with Manager. This reaffirmation or renegotiation is permissible as a matter of contract law. Because Firm itself cannot object to renegotiating the deal, no one who claims through Firm, such as Creditor, should be able to object either. Manager's renegotiation violates no interest of Creditor, regardless of who is doing the negotiating for Firm.

Consider now a variation on this case. There is a contract between Manager and Firm, as before, for Manager to develop software for Firm but, unlike before, Manager's performance is partly completed, and partly executory. Manager has delivered some software to Firm, is still developing other software, and has yet to be paid anything by Firm. In this case, Manager has a prepetition claim for work already completed, and in that case is indistinguishable from an ordinary creditor with a fully-matured claim. Manager may not, however, be in the position of an ordinary unsecured creditor with respect to this claim. Under ordinary rules of contract law, Manager may have the ability to suspend performance yet due unless and until Firm demonstrates its ability to pay Manager in full, including for the work already done. ${ }^{74}$

Even if Manager's past performance is a result of an entirely separate contract from the executory parts of her performance, however, Manager may have the right to suspend performance under the executory contract without assurance that the defaults under the earlier, nonexecutory, contract will be cured..$^{75}$ And if the

${ }^{72} 11$ U.S.C. $\$ 365(b)$ carries through this notion. A debtor can assume a contract only if it cures defaults and, if it defaulted prior to bankruptcy, if it provides adequate assurance of future performance. In addition, any future breach will, following assumption, be treated as an expense of administration.

${ }^{73}$ Contract law may police the substitute deal to ensure, for example, that it is "reasonable." See, e.g., Brian Const. \& Development Co. v. Brighenti, 176 Conn. 162, 405 A.2d 72 (1978).

74 U.C.C. $\S 2-607$ (1978). This rule is again continued by 11 U.S.C. $\S 365(\mathrm{~b})$.

${ }^{25}$ See Official Comment 3 to U.C.C. $\S 2-609$ :

Under commercial standards and in accord with commercial practice, a ground for insecurity need not arise from or be directly related to the contract in question. The law as to "dependence" or "independence" of promises within a single contract does 
question is whether Manager will continue to enter into software development contracts in the future, Manager's ability to make such contracts contingent upon Firm's compliance with previous contracts should be even clearer.$^{76}$ Under contract law, this right of Manager to withhold further performance without payment for work already done gives Manager the equivalent of a lien that makes its rights superior to those of general creditors. In those cases, a renegotiation with Manager that provided Manager with a piece of Firm in priority to that of Creditor violates no interest of Creditor and is likewise unobjectionable. ${ }^{77}$

not control the application of the present section.

Thus a buyer who falls behind in "his account" with the seller, even though the items involved have to do with separate and legally distinct contracts, impairs the seller's expectations of due performance.

In the example in text, Article 2 of the U.C.C. may be applicable only by analogy, as the contracts in question may not involve transactions in "goods."

${ }^{76}$ The last case comes close to the facts of In re Ike Kempner \& Bros. Inc., 4 Bankr. 31 (Bankr.E.D.Ark. 1980), which involved a question of whether the refusal of U.S. Shoe Co. to continue delivering Selby shoes to Ike Kempner, a shoe store, after Ike Kempner filed for bankruptcy violated the automatic stay. To consider this case, suppose that, when Debtor files for bankruptcy, it owes Supplier $\$ 40,000$ for prebankruptcy deliveries. Unless Supplier has taken a security interest in its shoes or in other assets of Debtor, this $\$ 40,000$ debt would be classified as an unsecured obligation of Debtor for purposes of bankruptcy. Supplier then refuses to deliver any more shoes to Debtor unless Debtor pays, or promises to pay, the $\$ 40,000$ debt in full. Even if this refusal is clearly motivated by Supplier's desire to collect its $\$ 40,000$ in full, the action may not violate bankruptcy norms. Supplier may have a valuable property right, the right to refuse to deliver more shoes, that it could use outside of bankruptcy to ensure payment. Because this right would be effective against lien creditors outside of bankruptcy (who could not require Supplier to deliver shoes), its relative value vis-a-vis unsecured creditors should be respected in bankruptcy. (Where Supplier is a source of a fungible item such as wheat, the relative value of its nonbankruptcy right is close to zero.) Where Supplier can withhold future cooperation, it has rights that are, in many respects, similar to the rights of a secured creditor: it is simply setting the price on its future performance, and it does so in a situation where Firm must cut a deal with Supplier or have it walk. See also Matter of EDC Holding Co., 676 F.2d 945 (7th Cir. 1982); In re Blackwelder Furniture Co., Inc., 7 Bankr. 328 (Bankr.W.D.N.C. 1980).

${ }^{77}$ This would not be the case where Manager's original deal was that her performance was not contingent on payment by Firm (such as where Manager took a higher interest rate to compensate her for the downside risk). This seems like an implausible bargain. The linkage between firm-specific skills and being a debt-holder seems counterintuitive. But if it is the original bargain, Creditor would have grounds for complaint. The software program is owned by Firm outright. Manager is simply another owner of Firm. Manager has sold her firm-specific asset, the program, in return for a claim against the company. Manager has agreed to share pro rata with the general creditors.

But in this case, it is not just Creditor that has cause to complain. Like the cases where a creditor attempts to renegotiate an ongoing contract as a way to extract a monopoly rent, Firm itself can object. Bank has no more reason to agree to deal with Manager on this basis than Creditor does. Thus, not only are these cases unlikely to arise as a normative matter, but there seems to be no reason to find Bank and Manager striking a bargain that excludes Creditor in these situations and which accordingly require policing by some legal rule.

The need to ensure that junior owners have the right set of incentives even if the firm is 
To this point, we have assumed that the renegotiated deal was "permissible" as a matter of contract law. If Manager sought a renegotiation, not because Firm was not fulfilling its original side of the deal, but because Manager now simply believed that she deserved more for her work, Firm could insist on the terms of the original contract. But for the imperfections in the rules governing the enforcement of contracts, Firm would have no reason to renegotiate with Manager. Whether to renegotiate under these circumstances requires a careful assessment of how to work in a secondbest world. Those doing the negotiating for Firm should bear both the benefits and pay the costs of any deal struck. For this reason, one would expect the power of negotiation to be in the hands of the residual owner. Other things being equal, it will be best positioned to decide how to negotiate with Manager.

It is this point, we believe, that aids an examination of the rule of Boyd. In cases where Firm is insolvent, many doctrines, such as fraudulent conveyance law, worry about policing deals that are made for less than adequate consideration and provide enforcement rights to creditors. Return to the case in which Manager, who owns no equity in Firm at all, is paid $\$ 100,000$ up front to write a software program for Firm. Manager subsequently refuses to work unless she is paid an additional $\$ 50,000$. This demand, we shall assume, violates contract rules. ${ }^{78}$ Firm would be within its rights to refuse to accede to this renegotiation and hold Manager to her original deal.

Nothing changes in a recapitalization triggered by insolvency. As long as Firm is willing to pay Manager the original $\$ 100,000$, it can refuse this deal. The reason why we believe this is not a substantial problem, however, is that Bank's incentive, as the foreclosing creditor, does not diverge from that of Firm as a whole. Bank,

insolvent may be the explanation for the nonbankruptcy rule allowing dividends from current earnings, the so-called nimble dividends rule. See, e.g., Delaware General Corporation Law \& 170(a); Clark, Corporate Law at 617-18 (cited in note 41). The nimble dividends rule in any event is a nonbankruptcy rule that in contrast to Boyd, allows compromising the rights of creditors for the benefit of shareholders under conditions in which it seems in the interests of all the owners as a group.

${ }^{78}$ Renegotiation of existing contracts that result solely from the power a party gets in a contractual relationship are commonly analyzed, and prohibited, under the doctrine of "economic duress." See, e.g., Austin Instrument Co. v. Loral Corp., 29 N.Y.2d 124, 324 N.Y.S.2d 22, 272 N.E.2d 533 (1971); Selmer Co. v. Blakeslee-Midwest Co., 704 F.2d 924 (7th Cir. 1983); Alaska Packers' Ass'n v. Domenico, 117 F. 99 (9th Cir. 1902). See generally Subha Narasimhan, Modification: The Self-Help Specific Performance Remedy, 97 Yale L.J. 61 (1987); Richard A. Posner, Gratuitous Promises in Economics and Law, 6 J.Legal Stud. 411 (1977). 
following the foreclosure, is the owner of Firm. If Bank agrees to pay Manager an extra $\$ 50,000$, that payment comes at Bank's expense. Because Bank bears the costs and enjoys the benefits of any deal it strikes with Manager, we can rely on Bank to decide whether and when to agree to this deal.

Nothing in principle changes if the original deal between Firm and Manager was cast in the form of Manager's receipt of equity. Indeed, if, Manager's obligations to complete her performance were contingent upon her equity position being worth something, then Creditor could not object if Firm later struck a bargain with Manager that left Manager with an equity position. ${ }^{79}$ Absent a new bargain with Manager, Firm would have no right to the continued services of Manager. Creditor claims through Firm and can have no better rights than Firm has. This is just another example of a permissible renegotiated contract, one that Bank has the correct incentives to negotiate. If the original deal was that Manager would perform for Firm in return for an equity interest, irrespective of the value of that interest at any point, then Manager's renegotiation would violate contract rules, and could likewise be adequately policed by Bank.

Bank, following a foreclosure, moreover, has the right incentive to agree, or not, to a deal with Manager. Bank decides whether Firm is more valuable to it without Manager, in which case Bank owns all of Firm, or with Manager, but with some portion of the ownership of Firm passed to Manager. Creditor loses out not because of a transaction in which equity is preferred to debt, but because Bank, as the residual owner of Firm, is paying the price for an input that Firm needs to have value as a going concern. Like the acquisition of any new input for an insolvent enterprise, Creditor cannot complain if the cost of that input takes priority over its position. ${ }^{80}$ Creditors generally are entitled to a firm's income stream in priority to equity, but in this case Manager is wearing the hat of a supplier of future inputs as well as that of an equity owner. As long as the compensation given Manager is for being a supplier of future inputs, Creditor has no cause to complain, unless

79 Again, "something" is admittedly vague, leaving open the possibility that Creditor-as Firm itself-could object if Manager claimed "too much" relative to the original understanding.

so Consider the case where Bank is negotiating with Manager to write the software and with Writer to write equivalent software. Any deal struck between Bank and Writer, including one involving equity, would not be subject to attack by Creditor. Bank should not be handicapped in its negotiations with Manager over a competitive input by a rule that introduces Creditor into the negotiations with Manager, but not with Writer. 
Bank has the wrong incentives to cut an appropriate deal with Manager, which, as we have seen, is not the case.

In short, Creditor is squeezed out because it brings nothing of value to Firm's continued operations. Bank contributes assets; Manager contributes firm-specific skills. While Creditor's argument is premised on its purported entitlement, by preexisting contract, to any remaining value of Firm as a going concern in excess of that going to Bank, before Manager receives anything, that argument fails to confront Manager's uncontrollable ability to withdraw her asset, the expertise, at any time, and for purely selfish reasons. This latter right gives Manager a power that she has not contracted away to Firm at the time of the original deal. In effect, Creditor in reality enjoyed a right to the income stream of Firm in priority to that of Manager only in cases in which two conditions held: Manager decided to continue to work for Firm and Firm was not in default as against Bank. There is no transfer of wealth from Creditor to the holders of equity in cases in which the rules are defined to allow the holders of equity to walk and take a valuable input, future services, with them and do anything with it, including recombining that input with Bank in Firm. ${ }^{81}$

In this part of the paper, we have focused on the case in which the senior owner wanted to recombine with the old shareholder, but our analysis would apply equally well to any situation in which a junior owner bargains after the fall. Although neither commentators nor courts have linked the problems of the striking workers, the post-petition lender, and the post-petition supplier with the problem of the owner-manager with expertise, they are all the same. ${ }^{82}$ The rationale of Boyd applies equally well or equally poorly to all of them.

We would argue that the only difficulty peculiar to bankruptcy

${ }^{81}$ The classic fraudulent conveyance involves the owner lining her pocket at the expense of the creditors when there is no reason to think that the owner has any special expertise to begin with. In the case we examine in text, however, if Manager has no special skills, then there will be no deal to cut with Bank and no freeze out will occur. There might be a valuation worry-Bank asserts that the liquidation value of the assets is $\$ 135$ when it in fact is $\$ 180$-but the response to this problem would not seem to be the rule of Boyd, which prohibits the freeze out irrespective of valuation worries (as, indeed, the valuation in that case was established by a judicial foreclosure sale). The question of what constitutes reasonably equivalent value in the fraudulent conveyance context is explored in Douglas G. Baird and Thomas H. Jackson, Fraudulent Conveyance Law and its Proper Domain, 38 Vand.L.Rev. 829 (1985). We have argued that the question of what constitutes reasonably equivalent value becomes problematic only in situations in which a decision that had distributional consequences among the owners of the firm also had an effect on how the assets of the firm were deployed. That problem is not implicated here.

${ }^{82}$ See notes 55-56 and accompanying text. 
in any of these cases lies in the problems associated with identifying the residual owner and establishing a mechanism that allows the residual owner to bargain effectively. In many cases, the residual owner may be not a single senior owner, but rather a large group of general creditors, not all of whom can be identified. The trustee in bankruptcy acts on their behalf, but like any other agent the trustee represents the interests of the principal imperfectly. Moreover, under existing Chapter 11, the interests of the residual owners continue to be represented by the old managers. The agency cost problems are apt to be especially acute.

To the extent that our critique of Boyd is right, the law of corporate reorganizations should focus on identifying the residual owner, limiting agency problems in representing the residual owner, and making sure that the residual owner has control over the negotiations that the firm must make while it is restructuring. Except for the changes in residual ownership that are themselves the occasion for the restructuring, the rules governing these negotiations should be the same as those that exist even when a financial restructuring is not taking place.

\section{The Costs of Implementing Boyd}

To this point, we have assumed that renegotiations took place because the junior owner was bargaining over her future participation in the firm. We have argued that in these cases, the firm should be able to decide whether to engage in negotiations and that, as is the case elsewhere, the residual owner of the firm should have the power to bind the firm. In this part, we assume that the renegotiations arise from some other source. We assume that the renegotiations are the product of collusion between the senior and junior holders or represent some other form of bargaining that the intermediate creditor would, if possible, bargain for the right to prohibit.

Even assuming that the intermediate creditor has grounds for complaint when it is squeezed out of its right to enjoy the benefits that would come its way if Firm does better than expected, benefits it enjoys before the junior owner, one must show that a set of procedures can be devised to take account of these rights. If these procedures were too costly and cumbersome, everyone would be better off if the senior and junior owner could negotiate as they would in the two-party case. The intermediate creditor could be compensated for the undercutting of its priority position at the outset.

We shall again assume that the senior, intermediate, and jun- 
ior owners are Bank, Creditor, and Manager respectively. Any rule that takes account of the rights of Creditor must first distinguish those cases in which Creditor would not have received anything even if Firm succeeded and those in which Creditor's rights have some value. For example, even if Creditor's argument were otherwise valid, it should fail when Creditor's claim against Firm is worthless under any scenario. Assume, for example, that Bank is owed $\$ 300$ and in no case will Firm earn more than $\$ 200$. In this case, the interest of Creditor has no value even if Firm remains intact. Manager captures nothing that Creditor had a right to. There were no assets subject to creditor levy before or after the transaction. Under these facts, Creditor has not had anything taken from it.

To accept Creditor's argument, and hence Boyd, we must identify those cases in which there is a potential gain that Creditor might be able to enjoy (such as when Bank is owed \$150) and those in which there is not (such as when Bank is owed $\$ 300$ ). In addition, the rule must try to devise a set of procedures that will allow Creditor to vindicate the value of its right. Boyd itself stands only for the idea that one cannot rely entirely on market-sale procedures when the vice is one of squeezing out an intermediate class from a potential gain to which it is entitled. Boyd, at best, raises a potential objection to foreclosure sales followed by recombinations: These procedures may allow a junior party to recapture an asset that belonged to an intermediate party. Boyd itself, however, does not tell us how the rights of Creditor are to be determined.

The bankruptcy proceeding itself allows all the parties to negotiate with one another. As such, it satisfies one part of the Boyd objection, as it provides a forum for an intermediate class to force a valuation procedure to determine what its baseline entitlements are. But bargaining inside of bankruptcy, like bargaining elsewhere, must proceed from a baseline and nothing in the logic of Boyd suggests what this baseline should be. The evolution of the absolute priority doctrine after Boyd seems to have moved uncritically from one of identifying the problem of the freeze out of an intermediate class to setting the baseline entitlements of each class.

The first objection one can make to the existing absolute priority rule is that it wholly ignores the possibility that the claim of the intermediate class is worthless. According to the floor statements concerning $\S 1129$ (b) of the Bankruptcy Code, it always vio- 
lates the absolute priority rule to "skip over" a dissenting class. ${ }^{83}$ Those statements note that "a senior class will not be able to give up value to a junior class over the dissent of an intervening class unless the intervening class receives the full amount, as opposed to value, of its claims or interests." 84 Such a rule forces allocations to Creditor even in cases where Creditor was entitled to nothing either in a liquidation or in a continuation, absent the recombination, such as the case in which Bank is owed $\$ 300$ and Firm will never be worth more than $\$ 200$.

Moreover, the absolute priority rule in its current form collapses the three-party negotiation into a two-party negotiation by setting the value of Bank's claim at the amount it would have been able to realize from a sale to a third party. This rule can be correct only if Bank has no right to the going-concern surplus. But Bank would be able to capture this entire surplus if Manager had no hold-up power. This approach neglects the vice of the foreclosure followed by a recombination, which is not that Bank benefited at Creditor's expense, but rather that Manager did. One cannot argue that Creditor is entitled to the going-concern surplus in priority to Manager and at the same time argue that Creditor's right is not subject to Bank's. By assumption, Bank has a senior interest in all the assets of Firm. ${ }^{85}$

${ }^{83}$ Unless, perhaps, the lower class contributes new value. We criticize, however, in Part $\mathrm{I}$, allowing junior owners to participate in the revised firm as of right by contributng new value in the two-party case. This issue has been the focus of recent litigation about the absolute priority rule.

84 The floor statements in lieu of a conference report do suggest, that "unlike the fair and equitable rule contained in Chapter $\mathrm{X}$ and $\S 77$ of the Bankruptcy Act, under $\S$ $1129(\mathrm{~b})(2)$, senior accepting classes are permitted to give up value to junior classes as long as no dissenting intervening class receives less than the amount of its claims in full." 124 Cong.Rec. 32407 (Sept. 28, 1978). That problem, however, is distinct from the one focused on in text.

The Senate bill would have permitted a sharing with a junior class of a senior class' entitlements over the objection of an intervening class. Bankruptcy Reform Act of 1978, S.Rep.No. 95-989, 95th Cong., 2d Sess. 127 (1978), noted that "[p]aragraph 9(A) [of § 1129] would permit a senior creditor to adjust his participation for the benefit of stockholders. In such a case, junior creditors, who have not been satisfied in full, may not object if, absent the 'give up,' they are receiving all that a fair and equitable plan would give them."

${ }_{83}$ The issues at stake in the three-party case can be seen more clearly by looking again at bargaining when there are only two parties. Assume that in the two-party case in which a single creditor, Bank, is owed $\$ 150$, Manager would be able to persuade Bank to waive its right to force a sale of Firm by executing a personal guarantee and that she has a net worth of $\$ 30$. In this case, the value of Bank's interest in Firm as a going concern is $\$ 140$. (There is a 50-50 chance Firm will be worth $\$ 200$ and Bank will be paid in full; there is also a $50-50$ chance Firm will be worth $\$ 100$, in which case Bank will also be able to draw on the guarantee and recover a total of $\$ 130$.) Hence Manager's equity interest, net of the costs of issuing the guarantee, is worth $\$ 10$. 
Setting a baseline for the three-party negotiation is like solving a circular priority. ${ }^{86}$ One needs to know the outcome of the two-party case, but there is no way to establish which two-party case provides the appropriate starting point. The problem, in short, goes beyond the problem of valuing rights of the parties.

But one cannot transport this two-party bargain automatically into the case in which there are three parties. In a world that did not have the Boyd rule and Bank and Manager could squeeze Creditor out, we could not be certain that Bank and Manager would reach the same deal that Bank and Manager would reach if Creditor's claim did not exist. In the twoparty case, Manager's interest in Firm if Bank did nothing was worth $\$ 25$. There was a 5050 chance that Firm would be worth $\$ 200$ and $\$ 50$ would be left for Manager. In the threeparty case, Manager's interest in Firm if Bank did nothing would be worth only $\$ 5$. (Even if Firm turned out to be worth $\$ 200$, there would be only $\$ 10$ left after Bank and Creditor were paid.) The same deal in the three-party case in which Manager proposes to execute a guarantee affects the parties differently. In the first instance, Manager's offer to execute the guarantee conveys less information about the value of Firm to Bank. In the two-party case, Manager uses her own money to buy off Bank's right to foreclose. In the three-party case, she uses Creditor's. In the first case, her interest in Firm in the absence of Bank's right to declare a default drops from $\$ 25$ to $\$ 10$. In the second case, her interest rises from $\$ 5$ to $\$ 10$.

Determining how Bank and Manager would negotiate with one another if Creditor were not in the picture might nevertheless provide a benchmark for Bank's rights. But it is not clear that the proper rule is to give Bank $\$ 140$ and then allow Creditor and Manager to reach a deal over what remains. This approach does collapse the three-party deal into a twoparty deal, assuming that one could determine what the bargain between Bank and Manager would have looked like, but there are other ways to collapse the three-party deal into a two-party deal.

One might, for example, ask what negotiations would look like if Bank's and Creditor's claims were combined and a renegotiation took place. Would Bank strike the same deal with Manager if it were owed $\$ 190$ instead of $\$ 150$ ? This case is different from the first in that Bank's liquidation value is now less than the going-concern value. It cannot extract an additional contribution from Manager by threatening to shut Firm because it is better off if Firm stays intact. The value of Firm to it as a going concern is $\$ 145$ rather than $\$ 125$. Manager, rather than Bank, is the one who is likely to threaten Firm's existence as a going concern. A renegotiation, if it took place at all, would involve Bank both giving up its default right and compromising some of its claim. There is little reason to believe that Bank in this case would compromise its claim by $\$ 5$ and leave Manager with an interest worth $\$ 10$. If one chose this two-party bargain as the benchmark, one would still be left with a two-party negotiation except it would be between Bank and Creditor instead of Creditor and Manager.

One could also posit the negotiations that would take place if Bank and Manager, before they reached their own deal with each other, tried to buy Creditor out. For how much would Creditor be willing to compromise its claim in the face of Bank's threat to foreclose? Again there is no reason to think that Creditor would bargain in the same way as Manager would bargain with Bank in the two-party case and settle for an interest in Firm worth $\$ 10$. The bargaining range is the same. Bank would never give more than the difference between its estimate of Firm as a going concern and the amount it could realize from a sale to a third party, but Creditor, unlike Manager, contributes nothing of value to Firm, and has different and, in virtually all cases, less knowledge about the value of Firm. Protecting Creditor in this way may have the effect of undervaluing Bank's priority right relative to Creditor.

${ }^{86}$ These are cases where $\mathrm{A}$ has priority over $\mathrm{B}, \mathrm{B}$ has priority over $\mathrm{C}$, and $\mathrm{C}$ has priority over A. See Note, Circular Priority Systems Within the Uniform Commercial Code, 61 Tex.L.Rev. 517 (1982). The problem can be generalized, as demonstrated by the social choice theorem. See Kenneth J. Arrow, Social Choice and Individual Values (2d ed. 1963). 
There is no way to establish the set of initial entitlements. The bargaining is not over an entitlement with an ascertainable market value, but over the power of one of the players to hold up the others. The value of this power itself is driven by the rules governing the negotiations. One cannot derive the one from the other.

In its present form, even assuming that, as a normative matter, Creditor has grounds to complain in principle; one must choose among various baselines, all of them arbitrary in the same sense that any resolution of a circular priority is inherently arbitrary. For this reason, wholly practical considerations may govern the choice of the baseline. One could give Bank the right to the entire going-concern surplus, even though it has no ability to exploit it without making a deal with Manager. This result, like the Boyd rule itself, seems contrary to the bargain that the parties would like to strike with each other, but it avoids the two valuation problems inherent in the existing absolute priority rule. One does not have to distinguish those cases in which Creditor's interest has no value even in the absence of the exercise of a default by Bank from the cases in which it does. Second, one does not need to have a procedure that identifies the level of Bank's entitlement. Recall from our discussion earlier that it will not be easy in any case to determine what Bank would be entitled to in the event of default. One will not be able to obtain a market value for this right because Firm will not be liquidated but will be kept intact as a going concern.

If experience under Chapter 11 has shown anything, it is that valuation procedures are cumbersome when used rigorously and are ad hoc in many instances. Because the Boyd rule requires difficult valuation procedures, its baseline, one that gives Creditor, but not Bank, a right to the going-concern surplus, may be too costly to implement. Moreover, even if a set of valuation procedures were thought a necessary response to a threatened freeze out, the current procedures of Chapter 11-where many of the rights and powers are given not to the intermediate class but to the class of equity owners $^{87}$ - would be hard to justify. It would be perfectly appropriate to use the procedures of Chapter 7 to effect the sale, but to require, at the request of an intermediate class, a valuation of its interest according to an absolute priority rule entitlement as measured by the greater of its going concern or its liquidation entitlement. Then any subsequent recombination between Manager and

${ }^{87}$ See In re Lionel Corp., 722 F.2d 1063 (2d Cir. 1983). 
Bank $^{88}$ would be prohibited without the consent of Creditor unless Creditor received its absolute priority rule entitlement, whatever that might be. In any other case, it would be necessary to negotiate with Creditor before Manager could participate in the recombination.

There is another reason to reject Boyd. It is easier to contract into the Boyd rule than to contract out of it. Firm can enter into employment contracts and the like with Manager that have the effect of binding her to Firm absent a renegotiation of the original deal. At the time Firm and Bank originally enter into their secured deal, moreover, Bank could commit not to engage in a freeze-out restructuring without a valuation proceeding or the like. Firm could bind itself in its corporate charter not to engage in transactions that froze out intermediate creditors. Even if this tactic was not foolproof, it is hard to see how the parties can successfully contract around Boyd. Bank and Firm cannot unilaterally waive the interests Boyd gives Creditor. ${ }^{89}$ Absent an agreement with each creditor, the rule of Boyd is hard to avoid.

There is one more point that needs to be considered. The senior creditor may be negotiating with the junior owner not because the junior owner has anything to contribute to the firm or because the senior and junior owner are colluding to freeze out the intermediate creditor, but simply because the senior creditor is buying off the junior owner so that it does not obstruct the reorganization. Indeed, if the junior owners are not contributing new capital and if only some of them even arguably have managerial expertise, that all junior owners are participating in the reorganized venture may be evidence that they are being compensated only for the hold-up power that they have and that the intermediate creditors lack. Nothing else easily explains the willingness of the senior creditor to give a piece of the reorganized firm to everyone in the most junior class.

But this explanation for the renegotiation does not support the Boyd rule. The Boyd rule converts a two-party negotiation into a three-party negotiation. Requiring the consent of yet another class of owners before the reorganization can go forward may compound the hold-up problem. Instead of eliminating a hold-up problem, it introduces another. What one must determine is whether

${ }^{88}$ Bank could buy the assets at the foreclosure sale by bidding in its claim.

${ }^{80}$ Firm could try to put it in its corporate charter, and thereby bind any creditor. Whether such a corporate charter provision would bind creditors at all, however, is uncertain; it is extremely unlikely that it would bind nonconsensual creditors. 
the power the junior creditors are exercising should exist. Because a right in Chapter 11 is exercised through a forced sale rather than a market sale, each group of owners is given a set of procedural rights to make sure that the value of their rights is respected. If the junior owners are bargaining away rights to procedures that are not worth using in that particular case, but which are worth using generally, negotiations between it and the senior creditor are appropriate. As in the ordinary case, the senior creditor as the residual claimant is best positioned to negotiate. If the junior owner is exercising powers that it should not have, legal rules should confront that problem directly by curtailing them.

\section{Multiple Senior Creditors and Allocation OF THE GOING-CONCERN SURPLUS}

To this point, we have treated the three-party case as one involving three distinct hierarchical classes: A senior class, an intermediate class, and a junior class. Each class, we posited, was entitled to the assets of Firm, as well as its income stream, ahead of the next junior class. But, in fact, many deals will be more complicated. Bank might have a security interest in only some of Firm's assets. Or Bank might have a security interest in Firm's real property while Finance Company has a security interest in Firm's personal property. In these cases, can we say anything about who is entitled to the "going-concern" surplus Firm generates if it continues? As between Bank, Finance Company, and Creditor, who has first dibs to the $\$ 15$ that cannot be allocated, by a third-party sale, to any particular asset?

The question we wish to raise here is what happens when, instead of having a priority to everything in Firm (such as is the case with debt as compared to equity), the focus is on creditors who have taken security interests in assets. Is a creditor that takes a security interest in "all" the assets of a firm in the same position as someone with a blanket priority with respect to everything over a lower class, or is the focus necessarily on particular assets (and hence their liquidation value)? We explore this first by considering a creditor that takes a security interest in a particular "hard" asset, such as a computer. We then address the question of whether any secured creditor can claim the going-concern surplus, as we have defined it, ahead of the class of unsecured creditors.

Start with the case where, as before, Firm's assets have a liquidation value of $\$ 135$ and a going concern value of $\$ 150$. One creditor, Finance Company, has a properly perfected security interest in a computer, one of Firm's assets, with a liquidation value of $\$ 27$. 
The question we wish to explore is whether Finance Company, by virtue of its security interest in the computer, has a claim to any of Firm's going-concern surplus in priority to the general creditors. ${ }^{90}$

One could allocate the going-concern surplus among creditors according to the ratio of each secured creditor's liquidation value to the assets' total liquidation value. For example, in our case, because Finance Company has a security interest in Firm's computer, with a liquidation value of $\$ 27$, one could allocate 20 percent of the going-concern surplus, or $\$ 3$, to Finance Company. ${ }^{91}$ The remainder would be allocated to other secured creditors, if there were any, or to unsecured creditors, if there were none. Under this view, unless and until Firm were liquidated, Finance Company was entitled to the returns from the use of the computer in Firm's business and, absent any better information about the relative importance of one asset to another, allocating 20 percent of the returns to an asset that comprises 20 percent of the liquidation value of Firm is the best available allocation.

We reject an allocational scheme that gives Finance Company any interest in the going-concern surplus, however, not simply because it is too cumbersome, but also because it seems inconsistent with the notion of asset values we have been considering and it ignores the source of the going-concern surplus. It seems wrong to say that the only relevant assets are the assets that would fetch $\$ 135$ on a liquidation. Manager contributes an asset as well, in the form of expertise. Because Manager has taken an equity position in the capital structure of Firm below that of all the creditors, it seems correct to say that the creditors, as a group, are entitled to the returns from that asset in priority to Manager, but incorrect to say that it is not an asset at all. It seems preferable to say that there is $\$ 27$ contributed by the computer and $\$ 15$ contributed by Manager's expertise. One should not automatically allocate that $\$ 15$, therefore, as if some of it were due to the computer. Thus, we believe, a secured creditor with a security interest in specific "hard" assets should be treated as having a claim to the asset's liquidation value. Its secured claim should reach no further. ${ }^{92}$ This

${ }^{80}$ Of course, as before, the creditors as a group have priority over equity to that surplus.

21 That is, with a total liquidation value of $\$ 135$, Finance Company's collateral comprised 20 percent of that value; $\$ 3$ is 20 percent of the $\$ 15$ total going-concern surplus.

${ }^{82}$ Perhaps it would be more accurate to express this as a case where the liquidation value and the going-concern value of the asset are the same. Thus, one does not have to say that one is using liquidation values. Moreover, if one defines, for purposes of using the absolute priority rule, a claimant's minimum entitlement as the greater of liquidation or going- 
suggests, moreover, that the question over the use of liquidation or going concern valuations for purposes of applying $\S 1129(\mathrm{~b})$ 's absolute priority rule is largely one of semantics. In the typical case of a secured creditor, they are one and the same. ${ }^{93}$

This conclusion, however, does not undercut the idea that a creditor should be able to bargain for a priority interest in the going-concern surplus in priority to other creditors. ${ }^{94} \mathrm{We}$ assumed in Part II that Bank had priority in all the income stream of Firm over Creditor. As a matter of subordination agreements and the like, that is certainly possible, but is it possible as a matter of taking security interests? That is, can Bank in fact take a security interest in "all" the assets of Firm in such a way as to give it priority over other claimants to the $\$ 15$ contributed by Manager's expertise? We see nothing in logic or existing legal rules that prohibits such a result-that prohibits, in other words, a completely hierarchical ordering of claims to a firm among creditors. Article 9 facilitated taking a security interest in "all" the personal property of a debtor, including collateral that could not otherwise be categorized. Under that scheme, the claimant that takes a security interest in Firm's "accounts"95 or "general intangibles"'96 should, as a

concern values, one can then deal with the one case, accounts, where we discern a difference between the collateral's liquidation and going-concern values.

${ }^{23} 11$ U.S.C. $\$ 1129$ (b)(2)(A) provides for either (a) the retention of the lien, (b) the sale of the property with the interest attaching to the proceeds, or (c) receipt of "deferred cash payments totaling at least the allowed amount of such claim, of a value, as of the effective date of the plan, of at least the value of such holder's interest in the estate's interest in such property." Notwithstanding this result, many seem to think that a secured creditor's entitlements are measured by the going-concern value of the collateral. See, e.g., In re Timbers of Inwood Forest Associates, Ltd., 808 F.2d 363, 373 (5th Cir. 1987 en banc), aff'd, 108 S.Ct. 626 (1988) ("its secured claim is valued on a going concern basis in connection with a plan of reorganization, and the secured creditor is not compelled to liquidate its collateral at forced-sale prices"); Brief for Amici Curiae National Association of Credit Management, Kenneth N. Klee, and Richard Levin in Support of Respondent, in United Savings Association of Texas v. Timbers of Inwood Forest Associates, Ltd. 26 (1987) ("the increased going concern value of collateral resulting from a successful reorganization inures fully to his benefit and need not be shared with other creditors") (availabie on Lexis: GENFED library, BRIEFS file). But as we have suggested here, the going-concern surplus due to managerial expertise is not properly allocated to other assets; nothing in 11 U.S.C. 1129(b) suggests measuring the value of the claim in a way that allocates such a surplus to other assets. In certain other cases, however, the distinction may have some force.

94 This question is limited to claims to priority arising because of security interests. As we have seen, blanket priority claims, such as debt over equity, and contractual subordination agreements do not raise this problem.

${ }^{85}$ U.C.C. \$ 9-106 (1978) defines an "account" as "any right to payment for goods sold or leased or for services rendered which is not evidenced by an instrument or chattel paper, whether or not it has been earned by performance."

${ }^{88}$ U.C.C. $\$$ 9-106 (1978) defines "general intangibles" to mean "any personal property (including things in action) other than goods, accounts, chattel paper, documents, instru- 
matter of logic, be able to claim the income stream generated by Manager's expertise. ${ }^{97}$

To assume that the $\$ 15$ generated by Manager's expertise would always be allocated to Creditor in the examples set forth in Part II would mean that an asset of Firm exists that the creditors as a group are indisputably entitled to if Firm continues, but that creditors cannot take a security interest in. This result, we believe, is inconsistent with the all-encompassing nature and intent of Article 9 and with the more fundamental idea that parties should be able to create a financial structure for Firm in any way they please.

The category of accounts seems to capture the notion of Firm's future income stream, but the issue is one that parties to a transaction must resolve in their security agreement. One could reasonably allocate the $\$ 15$ generated by Manager's expertise to accounts and, accordingly, allocate it to the secured party with a security interest in Firm's accounts. Doing so seems to us to capture faithfully the meaning and intent of an "account" in the case where the account arises from services rendered by Firm. ${ }^{98}$ In those cases, the account clearly arises from labor inputs, and yet is allocated to the account financer in priority to other creditors. We see little reason to distinguish those cases from cases where the value being generated is partly derived from the expertise of Manager. Accordingly, we would propose that, in considering a complicated case and the absolute priority rule, the party with a security interest in accounts be treated as having first dibs to the $\$ 15$ generated by the expertise of Manager when considering Firm as a going concern. ${ }^{99}$ Indeed, except for the value of outstanding accounts at any time, we would assert that this is properly the only value that the party claiming accounts has a right to. ${ }^{100}$ One might

ments, and money."

${ }^{97}$ To be sure, it is an odd kind of collateral, as it cannot be levied on; only its income stream can be captured. But as the Supreme Court noted a half a century ago, things can look "like" liens notwithstanding the lack of a right of levy. See Chicago Board of Trade v. Johnson, 264 U.S. 1, 15 (1924).

${ }^{83}$ Even in the case where the account arises from the sale of goods, it also gives life to the notion of an account as something distinct from proceeds of the sale of inventory.

${ }^{99}$ Under Article 9, a "proceeds" interest in inventory may trump the holder of a security interest in accounts. We do not go into the complication of whether the prior inventory financer may trump the accounts financer with respect to the going-concern surplus.

${ }^{100}$ This might seem inconsistent with the interpretation of the absolute priority rule that otherwise seems to be based on liquidation values, not going-concern values. But this is not necessarily so. As we have defined things, the liquidation and going-concern value of most assets are the same. In those cases, using the liquidation value is the same as using the going-concern value. Only in the case of accounts (or general intangibles), as we have described things, do the two deviate, forcing one to choose. 
advance the argument that the going-concern surplus falls more easily into the defintion of a "general intangible." But regardless of whether parties mean to embrace this surplus by the use of the word "account" or "general intangible" in their security agreement, the important point is that a debtor should be able to grant a security interest in this asset. The absolute priority rule entitlement of such a creditor, then, is set by the greater of its collateral's liquidation or going concern value.

The party with the security interest in accounts should be able to cut a deal with Manager that "skips over" intermediate classes without violating the hierarchial ordering of ownership interests that parties bargain for at the outset. Consider a case where Finance Company, which is owed $\$ 30$, has a security interest in Firm's computer, with a liquidation value of $\$ 27$; Bank, who is owed \$150, has a security interest in Firm's going-concern surplus; Creditor, which is owed $\$ 40$, is unsecured. As before, Firm's assets are worth $\$ 135$ liquidated, and Firm is worth $\$ 150$ as a going concern. ${ }^{101}$ No accounts are outstanding at this point. ${ }^{102}$ Finance Company should be entitled to $\$ 27$, as its liquidation entitlement is the same as its going-concern entitlement. Bank should be entitled, as a secured creditor, only to the value of the going-concern surplus, or $\$ 15$ (the liquidation value of the accounts being zero), ${ }^{103}$ but is

There are cases where there might be a deviation between an asset's going-concern value and its liquidation value. For example, existing accounts may be more valuable when Firm continues than when it liquidates (and account debtors feel fewer consequences to not paying). Alternatively, at least where buyers have informational asymmetries, a particular asset, such as a drill press, might be more valuable in its present use, simply because it is specially tailored to the other assets of Firm. In those cases, where one is looking at the rights of a secured party holding a security interest only on the accounts or the drill press, and that party would not have the right, on default, to sell Firm's assets as a package, it would be correct to distinguish between the collateral's liquidation and its going-concern value.

101 As before, there is a 50 percent chance of Firm being worth $\$ 200$ in a year's time and a 50 percent chance of it being worth $\$ 100$. Since there is no relevant affect on the distribution to senior claimants in this example under either outcome, the discussion will simply use the unitary number of $\$ 100$. In other cases, of course, one would have to be sensitive to differences in distributions among classes.

${ }_{102}$ This is a simplifying assumption. One could of course posit a value to existing accounts of $\$ 10$, that would then create a liquidation value of $\$ 10$ for the accounts. It is analytically easier, however, to posit a liquidation value for accounts of zero.

${ }^{103}$ Bank might argue that it has a going concern entitlement of the entire $\$ 150$, as it has first dibs on the income stream of Firm through its security interest in accounts, as the income stream of Firm as a going concern will manifest itself as accounts. We reject that view, however, for Bank does not have a prior claim to any of Firm's assets that can be levied on, other than existing accounts, which we are assuming are nonexistent. To get the income stream, Bank must ensure that no other creditor levies on the assets-or Bank must purchase the assets so levied at a total cost of $\$ 135$. This case is distinct from our case in 


\section{free to share this with Manager if it wishes.}

We should also consider the case in which the value of collateral turns on whether it can be sold with other assets of the firm. Bank has an interest in a specially built machine tool and Finance Company a security interest in the custom-made dies used with it. If sold alone, the machine will bring $\$ 50$ and the dies $\$ 10$. The two together can be sold for $\$ 100$. Who is entitled to the extra $\$ 40$ that is gained from selling them together in bankruptcy? We have not addressed this question earlier, because the added value that comes from the use of two assets in conjuction with one each other is never an issue when a single secured creditor has an interest in everything. The single secured creditor would have to right to the entire $\$ 100$ because it has the right to sell both the machine and the dies together. A secured creditor who had a priority claim to both the machine and its dies would enjoy the value of the synergy between the two assets, regardless of whether the firm stayed intact or were liquidated. But we must consider the problem of synergy between assets when priority rights to them are not in the hands of a single creditor.

Outside of a collective proceeding, Bank and Finance Company have the right to only $\$ 50$ and $\$ 10$ respectively if each must exercise its nonbankruptcy foreclosure right on its own. If Debtor defaults to both simultaneously, and if they can cooperate, however, they would be able to capture and share the $\$ 40$ difference between the value of the assets sold separately and the value sold together outside of bankruptcy. Should Bank and Finance Company be entitled to share this $\$ 40$ differential inside of bakruptcy or should it be enjoyed by the general creditors? Should we try to guess how likely cooperation between Bank and Finance Company outside of bankruptcy would have been? If they are entitled to share, how is the $\$ 40$ to be divided between them? This problem may not be of great practical moment. Secured creditors typically bargain for a blanket security interest in everything or, alternatively, in specific assets, such as real property or motor vehicles, that are not apt to have a value that depends on their being sold in conjuction with some other distinct asset. But it is a problem that

Part II, where we assumed Bank had a blanket priority over all of Firm, both its hard assets and its income stream. In that case, Bank could acquire all rights to the assets simply by bidding in its claim against the assets, thus stopping the dismemberment (with bankruptcy appropriately standing by to solve any resulting collective action problem). But where Bank has a claim only to the accounts, it has nothing to bid in against when Firm's other assets are being liquidated. As a result, it seems appropriate to measure Bank's interest in Firm as a going concern as one of a $\$ 15$ interest, not a $\$ 150$ interest. 
needs to be considered nevertheless.

Given that cooperation between Bank and Finance Company outside of bankruptcy is possible, we would recognize that an argument could be made for dividing all (or perhaps only a part) of the $\$ 40$ between Bank and Financing Company. But the game to us does not seem worth the candle. Trying to determine whether the joint sale would have taken place and how the proceeds from it would have been divided is likely to be difficult and uncertain task. Largely for pragmatic reasons, we would allocate this $\$ 40$ to the general creditors. To be sure, the general creditors would not have enjoyed this $\$ 40$ under nonbankruptcy law. (Indeed, in the event of a separate nonbankruptcy foreclosure, this value would have disappeared altogether.) Nevertheless, this value must be allocated to someone, and much of the point of bankruptcy is to capture for the general creditors values that would be lost in a regime of individual debt collection. Moreover, the general creditors bear the costs of the collective proceeding that makes the joint sale of the two assets possible. Most important, however, given the failure of secured creditors to bargain for the $\$ 40$ differential explicitly and the uncertainty of the nonbankruptcy result, the simplest baseline in bankruptcy may be the best.

\section{ConCLUSION}

Renegotiations often accompany the financial restructuring of a firm. They provide much of the dynamics associated with a corporate reorganization. The reorganization itself vindicates the hierarchical ownership structure that those who contribute capital to a corporation typically bargain for. The legal rules governing the accompanying renegotiations, however, have been insufficiently studied, and existing legal rules seem, on their face, unlikely to be the ones for which owners of a firm would bargain.

The Boyd problem is a crucial piece in the corporate reorganization puzzle. Boyd is emblematic of one of the central premises of the law of corporate reorganizations - that the bargaining that takes place when a firm is restructured demands a special forum and special set of rules. This premise is fundamentally flawed. The ambition of a bankruptcy code should not be to ensure that everyone can participate in all post-petition renegotiations. There is no virtue in bargaining for its own sake. Bankruptcy law should ensure that fights about who owns a firm's assets should not undercut efforts to use them in the most beneficial way possible. The best way to achieve this goal is to identify the residual owners and give them the power to make decisions. The residual owners should al- 
ways be the ones who enjoy the benefits of making good decisions and incur the costs of making bad ones. The Boyd rule does not do this.

The continuing vitality of Boyd and its prohibition on negotiations between a senior residual owner and junior owners that ignore intermediate owners flow from two sources. First, Boyd is honored in the breach. The Supreme Court excepted the contribution of new cash from the reach of Boyd. ${ }^{104}$ Problems with workers who strike or suppliers who insist on payment of the balance owing in full are indistinguishable from the problem in Boyd, in theory, but not recognized as Boyd problems in practice. Managers who have firm-specific skills frequently do not own all the equity of the firm. When they are given equity and other shareholders are not, courts do not recognize a Boyd problem either.

Second, and more important, the renegotiations that Boyd complicates by insisting on the participation of another player often arise because of the procedural rules that the law of corporate reorganizations generates. As with equity receiverships at the turn of the century, the junior owners may have leverage, not because they have unique management skills, but because the rules of the game give them this leverage. A legal rule that regulates such negotiations, negotiations that do not bring anything of value to the firm, does not therefore seem inherently objectionable. But the Boyd rule in this context pushes the law of corporate reorganizations in exactly the wrong direction. By complicating negotiations that Chapter 11's procedures generate, Boyd makes two errors. First, it treats the symptom (the bargaining) rather than its disease (the inappropriate procedures). Second, it treats the symptom by making it worse. It turns a two-party bargaining problem into a three-party bargaining problem. The better course would be to try to eliminate the inappropriate procedures that give rise to the bargaining in the first place.

One of the attractions of the Boyd rule at first meeting is that it appears to respond to a freeze-out problem that neither nonbankruptcy law nor market sales can prevent. It seems to suggest that post-bankruptcy renegotiations must take place inside the kind of environment that the law of corporate reorganizations provides. We have shown in this paper that the distinguishing charac-

104 Even if they had not, senior creditors are often willing to allow contributions of capital on terms similar to the intermediate creditor's or contributions by anyone else that wants to pay for the right to take a residual interest in a firm that has already failed once. See In re Landau Boat Co., 13 Bankr. 788 (Bankr.W.D.Mo.1981). 
teristic of these negotiations-the presence of owners junior to the residual owner who would have a right to assets of the firm in absence of default-does not require a special set of rules. The problems associated with bargaining after the fall justify neither the absolute priority rule nor any other special rules. 